\title{
ADATTÁR
}

\author{
GROTTE ANDRÁS
}

\section{KÍSÉRLET NÉHÁNY MAGYARORSZÁGI ÖTVÖSJEGY FELOLDÁSÁRA XVII.}

Korábbi közleményeim folytatásaként magángyüjteményekben és a mükereskedelemben talált új ötvösjegyeket, illetve jegyváltozatokat kívánok bemutatni, és megkísérlem az új jegyek feloldását. A már közölt jegyek esetében most is általában Kőszeghy Elemér jegykönyvére, ${ }^{1}$ a pest-budai jegyeknél pedig P. Brestyánszky Ilona munkájára ${ }^{2}$ hivatkozom a jegy ottani folyószámával.

\section{Pest}

2014-ben a budapesti mükereskedelemben aranygyürü töredéke bukkant fel B:233 helybélyeggel, korábban már közölt pesti aranypróbával ${ }^{3}$ és kiírt „Thiel” mesterjeggyel.

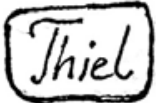

Kézenfekvő lenne a jegyet Thiel Károly új jegyeként meghatározni. Eddig Thiel Károly jegyeként a már Kőszeghy által közölt K:509 (B:309), összefont CT betükből álló jegyet ismertük.

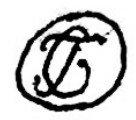

Ezzel egy Ratkovszky-címeres pecsétgyürü ismert a család tulajdonában, ${ }^{4} \mathrm{~K}: 444$ (B:184) próbajeggyel. Ugyanezzel a mesterjeggyel a Budapesti Történeti Múzeum 1937-ben Dr. Genthon Istvántól vett egy pecsétgyürüt B:184 aranypróbával és B:232 helybélyeggel, ${ }^{5}$ és talán ugyanezzel a mesterjegy- gyel volt 1984-ben árverésen egy férfi pecsétgyürü. ${ }^{6}$ A feltételes módot a katalógusban kérdőjellel jelzett meghatározás indokolja.

Németországi magángyüjteményből közöltek 2000-ben egy kereszt alakú arany függőt filigrán díszítéssel. ${ }^{7}$ Az 1820 körülre keltezett függőn B:184 aranypróba és B:233 helybélyegző mellett új mesterjegy volt.

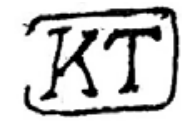

A jegyet a szerző Thiel Károly új jegyeként határozta meg. Kissé különösnek látszik, hogy az egyik jegy feloldása „Carl Thiel”, a másiké „Karl Thiel”. Ugyanezekkel a névbetúkkel egy másik ötvös is müködött Pesten: Testory Károly, akinek munkássága eddig ismeretlen.

Mindenekelőtt érdemes áttekinteni a rendelkezésünkre álló fontosabb életrajzi adatokat. ${ }^{8}$ Carolus Thiel civis aurifaber Dominicus Bergauer, a fócéhmester leányát vette felségül, Theresiát, aki 1795. május 16-án született. ${ }^{9}$ A házasságkötés pontos évszámát nem találtam meg. Thiel Károlynak öt leánya született. ${ }^{10}$ Theresia Bergauer 1829. március 20-án halt meg. ${ }^{11}$ Carolus Thiel újra nősült, hiszen tudjuk, hogy özvegye még 1839-ben is vezette a műhelyt. ${ }^{12}$ Ezt az évszámot többször Thiel Károly utolsó említésének tartották, ${ }^{13}$ pedig ő már 1830. április 14-én meghalt 48 évesen, ${ }^{14}$ vagyis 1782 körül születhetett. Ebből következik, hogy Thiel Keresztély (Christian Thiel) nem lehetett a fia, az ezt valószínüsítő véleménnyel ${ }^{15}$ szemben, ugyanis 1813. október 17-én kapta fel remekét, és ekkor már felszabadult inas volt, túl a kötelező három éves 
vándorláson is, azaz 18-20 éves lehetett. Mivel nem tudjuk, hogy mesterjogot nyert volna, őt kizárhatjuk a mesterjegy tulajdonosainak vizsgálatából.

Testori (Testory, Testoni) Károlyról, aki 1837ben lett mester, csak annyit sikerült megtudni, hogy nőtlen volt, és 1838. április 16-án halt meg 31 éves korában. Testvére lehetett Adolphus Testori aurifaber sodalis, aki 21 évesen 1832. január 12-én halt meg. ${ }^{16}$ Testori Károly, bár csak mintegy öt hónapig (1837. december - 1838. április) volt mester, és használhatott mesterjegyet, nem zárható ki a CT/ KT jegyek lehetséges tulajdonosai közül. Jó lenne, ha előkerülne olyan tárgy, melynek hiteles évszámos tulajdonosi vésete lehetővé tenné a megoldást.

Kissé bonyolultabb a kiírt „Thiel” jegy esete, még akkor is, ha Thiel Keresztélyt nem kell figyelembe venni. A19. század elején ugyanis még két Thiel (Thil, Till) működött Pesten. Wilhelm Thiel bürgerlicher Goldarbeiter és Amalia Lehman fia, Carl Wilhelm 1816. május 31-én született, ${ }^{17}$ keresztszülei Carolus Thiel és Theresia Bergauer voltak. Wilhelm Thiel nem sokkal később meghalt, mert özvegye 1819. július 10-én Joannes Holl aurifaber felesége lett. ${ }^{18}$ Valószínúleg rokon Georg Thiel is, szintén aurifaber, aki Mecklenburg-Schwerinben született, nős volt és 36 évesen, 1817. augusztus 5-én halt meg. ${ }^{19}$ Öt Horváth Henrik is említette arany- és ezüstművesként 1815 körüli működéssel, és Kapossy is ismerte, halálozási idejét is pontosan megadta. ${ }^{20}$

Mivel a Thiel család ötvöseinek múködési ideje átfedi egymást, a „Thiel” mesterjegy tulajdonosát, amíg olyan biztosan keltezhető tárgy nem kerül elö, mely kizárja valamelyiküket, nem határozhatjuk meg teljes bizonyossággal.

Érdemes még visszatérni arra a bizonyos 1839-es évszámra, melyet többször Carolus Thiellel, az ötvössel, hoznak kapcsolatba. 1833-ban egy bizonyos Carolus Till és Elisabetha Lehman, Joannes Holl és Amalia Lehman leányának, Aloysiának keresztszülei voltak. ${ }^{21}$ Nem tudom ki volt ez a Carolus Till, de ő lehetett az „okozója” a téves információnak.

P. Brestyánszky Ilona Blettl József B:235 mesterjegyével számos tárgyat ismertetett. A jegy különálló, kurzív „IB” betükből áll. Ennek változata került elő nemrég egy budapesti magángyüjtemény 1810 körül (B:120 próbajegy és $P$ évbetü) lekerekített nyéllel készült evőkanalán. A jegy jellegzetessége, hogy a kurzív betük felül összeérnek.

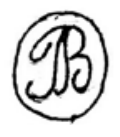

A mesternek korábban már számos jegyváltozatát közöltem. ${ }^{22}$ Ezek újraközléséről eltekintek.
Nemrég közöltem Starzer Antal pesti mesterként használt első mesterjegyét, ovális mezőben „AS" betűket. ${ }^{23} \mathrm{~A}$ mükereskedelemben most felbukkant egy újabb jegyváltozata egy romos állapotú, nagyméretü levesmerőn 1845-ös próbajegy mellett. A kanalat sajnos beolvasztották, de a jegyeket tartalmazó részt levágva, sikerült megmenteni. Az új mesterjegy a B:318, 319 jegyekhez hasonlóan „ASt" betűkből áll, de míg azok különállóak, az új jegyben az A és $S$ betüket összefonták.

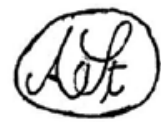

1824. március 25-én született Joseph Schöller katona-karmester (capellae militaris director) és Theresia Kopel fia, Carolus Schöller ezüstműves, aki 1866. február 10-én feleségül vette az 1834. március 30-án született Sidonia Kibonelt(?) (rosszul olvasható), egy órásmester leányát. ${ }^{24}$ Schöller 1856 óta volt a pesti céh tagja. B:315 mesterjegyével egyszerü tárgyak (teaszűrő, gyertyatartó, cukortartó) találhatók közgyűjteményekben (Iparművészeti Múzeum, Budapesti Történeti Múzeum) ${ }^{25}$ és hasonló tárgyak forognak a műkereskedelemben, magángyưjteményekben is, de felirata szerint ő készítette a pesti terézvárosi plébániatemplom aranyozott ezüstkelyhét is 1867-ben. ${ }^{26}$ Budapesti magángyüjteményben találtam kávéskanalakat Schöller újabb mesterjegyeivel.
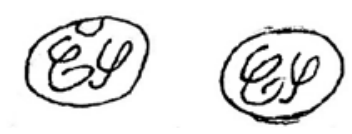

Az első jegy hegedű fazonú nyéllel, 1858-as próbajegyü kávéskanálon, a másik változat (a betük felett hiányzik a kicsi félkör) 1865-ös próbajegyü lekerekített végű nyéllel készült, és 1866-os próbajegyű, hegedű fazonú nyéllel készült kávéskanálon volt. Bár Schöller működését 1867-ig említik a céh irataiban, ő még ezután is dolgozott. Ugyanis egy másik magángyüjteményben a most másodikként bemutatott mesterjeggyel, hegedű fazonú nyéllel készült kávéskanalat találtam az 1867 és 1872 között használt Diana-fejes fémjellel és négyzetbe írt „P” hivataljellel jelezve. Megjegyzem, a B:315 mesterjegyben is van kicsi félkör a betűk felett, de annak még nem találtam félkör nélküli változatát (vagy nem figyeltem fel rá).

2007-ben árvereztek el Budapesten egy 14 karátos aranyból készült női gyűrűt (1. kép). ${ }^{27}$ A gyűrüben a pesti helybélyeg alig volt kivehető, de a B:185 1860 körül használt aranypróba és a mesterjegy jól látható volt. 


\section{SS}

A jegy az 1855. január 19-én mesterjogot kapott Schön Simon jegye lehet. ${ }^{28}$

\section{Brassó}

Andreas Gorgias 1652-1657 között Caspar Kriesch inasa volt. 1672-ben lett mester. Két fiát is az ötvösségre nevelte. ${ }^{29}$ A brassói evangélikus egyház őrzi egy paténáját, amelyről a jegyét Gyárfás lerajzolta. ${ }^{30}$

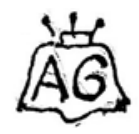

1999. augusztusában egy magángyüjteményben barokk örökmécsest láttam „AG” mesterjeggyel és 13-as próbával.

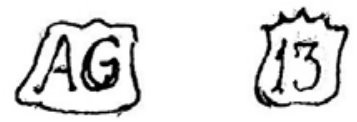

1999. szeptemberében pedig öt kést láttam egy másik magángyüjteményben „AG” mesterjeggyel és 13-as próbával.

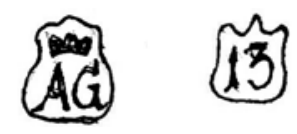

Mindkét jegy Andreas Gorgias jegye lehet. Korábban New Yorkban árvereztek el egy mellboglárt, mely 1675 körül készülhetett. ${ }^{31}$ Sajnos a jegyét külön nem közölték.

Andreas Mauthner Georg Olescher inasa volt 1706-1708 között. Csak két évig volt inas, mert a hátralevő időt a céh, mestere halála miatt, elengedte. 1712-ben lett mester, 1750-ben halt meg. ${ }^{32}$ Gyár-

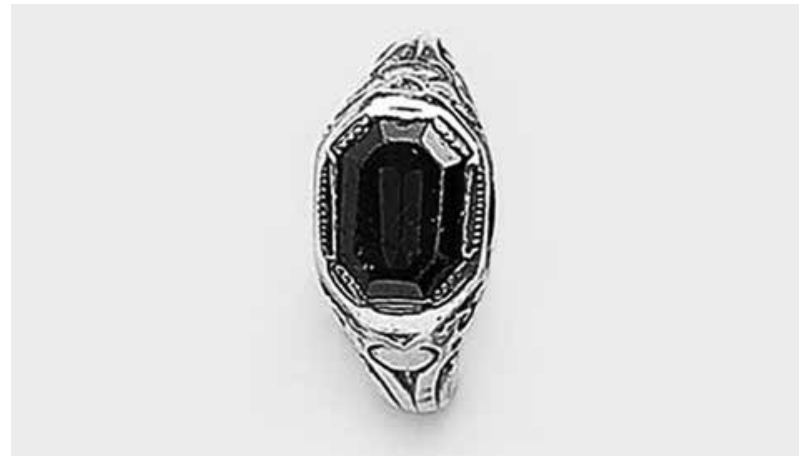

1. Gyürü. Pest, Schön Simon, 19. sz.

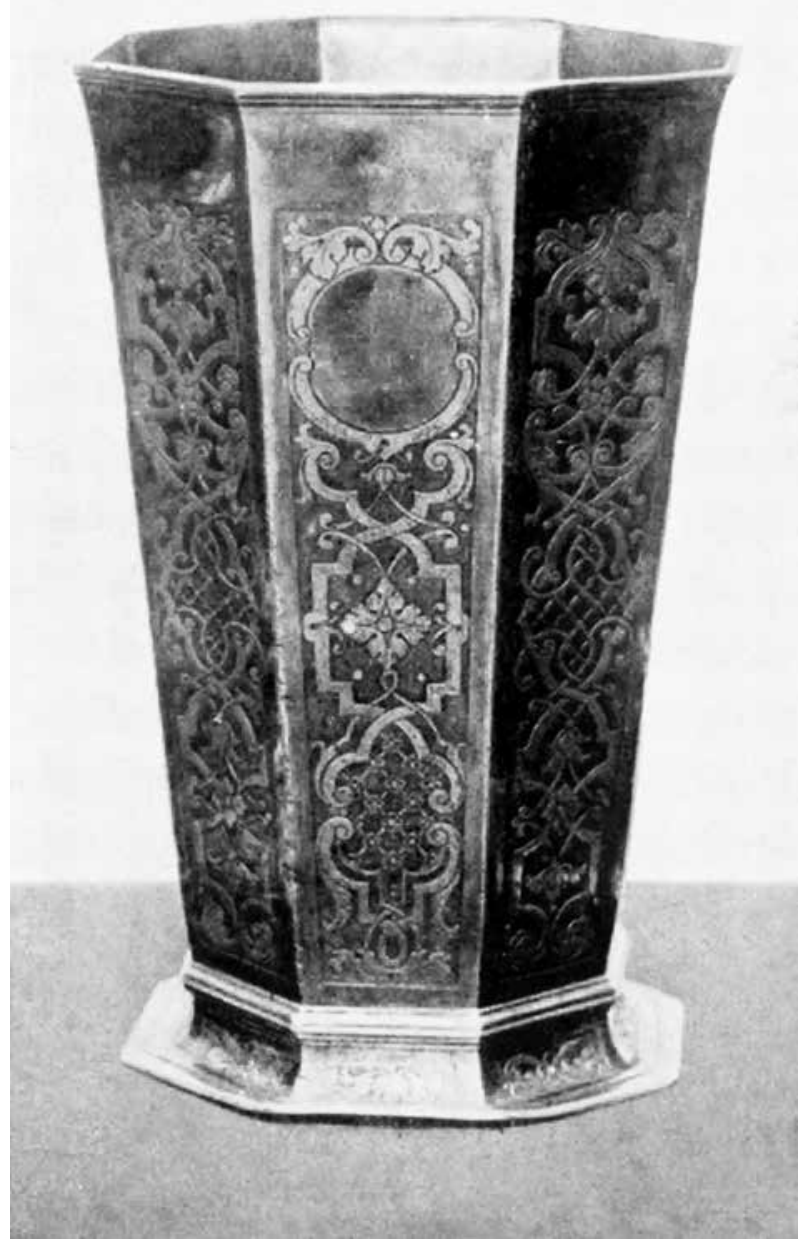

2. Nyolcszögletú pohár.

Brassó, Andreas Mauthner, 18. sz. eleje

fás 1910-ben a brassói zálogházban látott egy kis, pontozott díszítésü kerek poharat, fenekébe beütve koronás "AM" betűkkel. ${ }^{33} \mathrm{Ez}$ a jegy eddig máshol még nem került elő. 1927-ben és 1931-ben nagy, nyolcszögú poharát állították ki az Iparmúvészeti Múzeumban (2. kép). ${ }^{34}$ 2004-ben érmes poharát árverezték el Budapesten (3. kép), ${ }^{35}$ melybe új mesterjegyet ütöttek. A tárgyon csak mesterjegy szerepelt kétszer beütve.

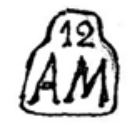

Lucas Römer 1715-1719 között inaskodott. Jacobus Gallnál tanult. Az egyetlen ötvös, aki a céh engedelmével vidéken dolgozhatott és ott is avatták mesterré 1724 körül. ${ }^{36}$ O készítette a brassói gö- 
rög-katolikus templom lámpáját 1756-ban, melyet a K:261 mesterjeggyel jelzett. ${ }^{37}$ 1922-ben sótartópárját árverezték el Budapesten. ${ }^{38}$ 1979-ben svájci árverésen szerepelt sótartója. ${ }^{39}$ Budapesti magángyűjteményben lekerekített végü, a merítőre gyémántmetszéssel felfutó nyelú kávéskanalat találtam új próbajeggyel.

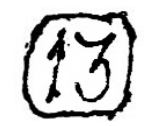

Joseph Benckner 1722-1726 között volt inas Stefen Welzernél, 1731-ben lett mester. 1783-ban

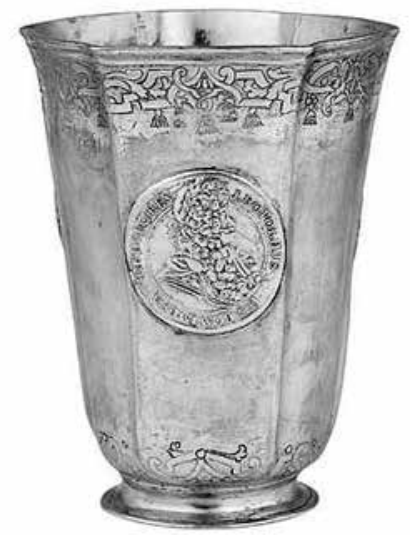

3. Érmes pohár. Brassó, Andreas Mauthner, 1730

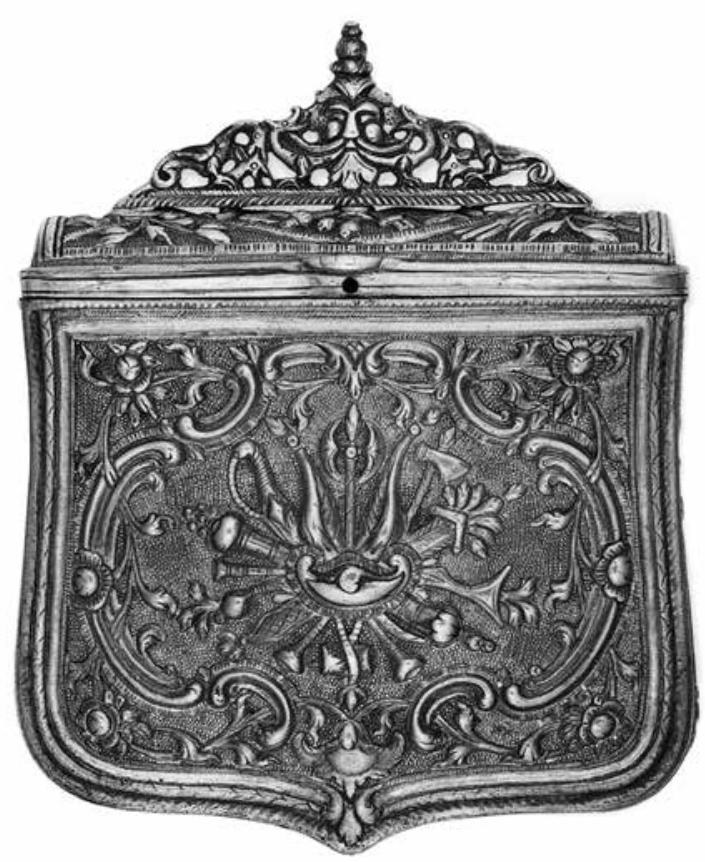

4. Tölténytáska. Brassó, Joseph Benckner, 1760 körül halt meg. ${ }^{40}$ K:265 mesterjegyével 1931-ben fedeles kupát állítottak ki Tószeghy Richárd tulajdonából, ${ }^{41}$ mely ma a Magyar Nemzeti Múzeum tulajdonában van és többször szerepelt kiállításokon. ${ }^{42}$ Rosenberg augsburgi magángyújteményből ismert ezzel a jeggyel fedeles kupát. ${ }^{43}$ Németországi magángyüjteményben volt 2000-ben nyolc boglárral és két nagy csattal készült öve, melyen új 12 latos próbajegy is volt, ${ }^{44}$

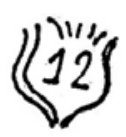

2003-ban pedig tölténytáskája a K:132 próbajegy mellett új, 13 latos próbajeggyel (4. kép). ${ }^{45}$

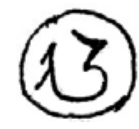

A tölténytáska 2012-ben Londonban árverésre került. ${ }^{46}$ 2005-ben Heilbronnban árvereztek el Benckner mesterjegyével egy, a Magyar Nemzeti Múzeum kupájához nagyon hasonló fedeles kupát

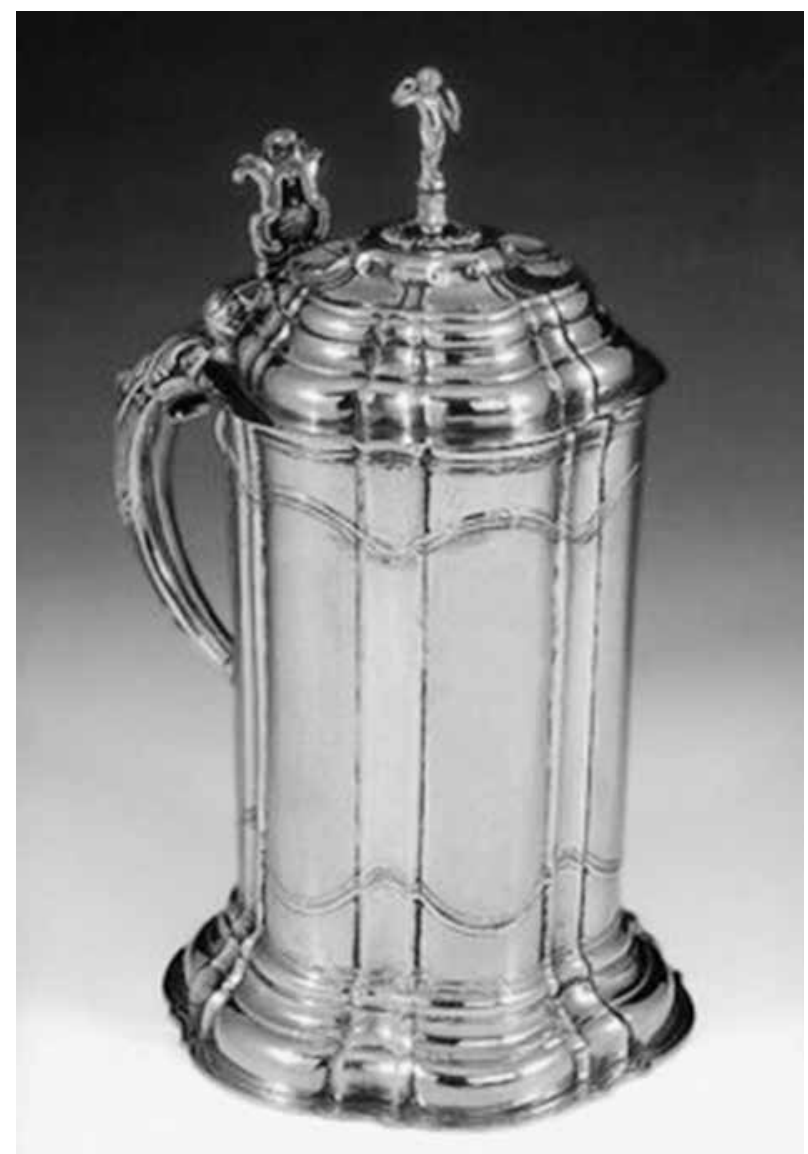

5. Fedeles kupa. Brassó, Joseph Benckner, 1730 körül 


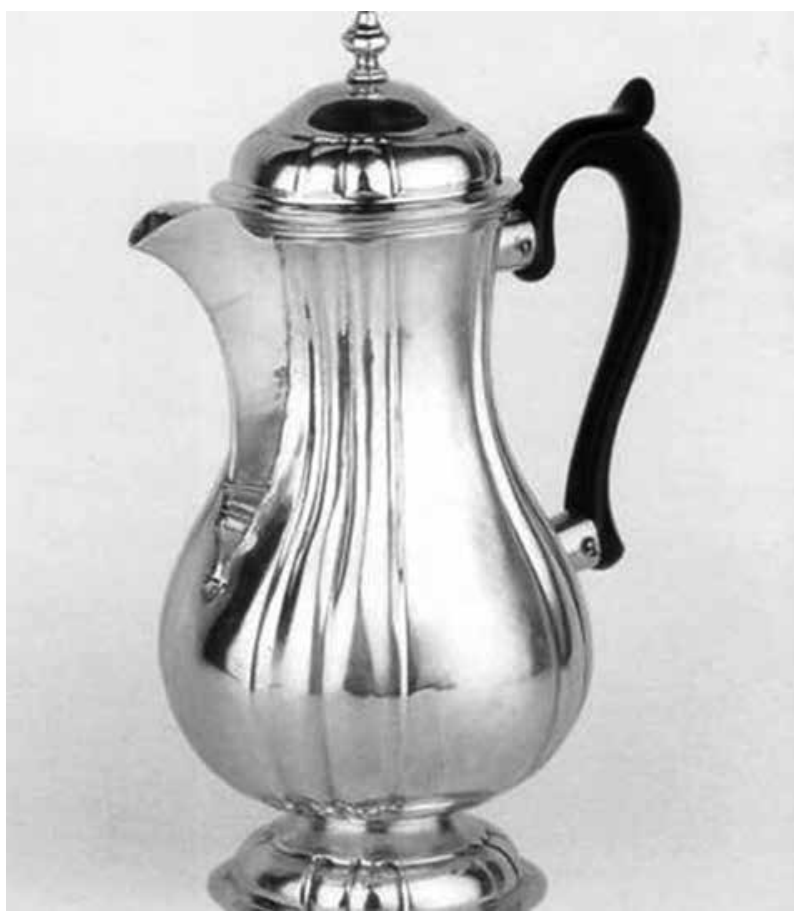

6. Kávéskanna. Brassó, Joseph Benckner, 1740 körül

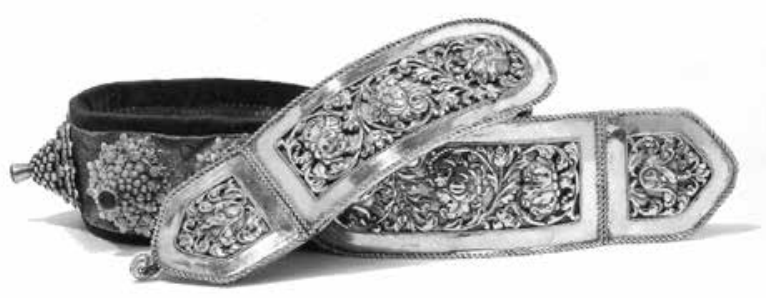

7. Szász díszöv.

Brassó, Christian Gottlieb Fleischer, 1850 körül

(5. kép). ${ }^{47}$ 1998-ban Budapesten került árverésre egy kávés kanna Benckner új mesterjegyével (6. kép). ${ }^{48}$

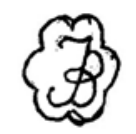

A kannát 2001-ben újra árverezték. ${ }^{49}$ Még 1988ban láttam egy budapesti magángyűjteményben Josephus Benckner K:265 mesterjegyével, egy tizenegy boglárral és két nagy csattal készült övet, melynél a csatolólánc rögzítő karikáján Henricus Jekelius K:291 vagy K:292 mesterjegye volt. Ez későbbi javítás jele lehet.

Christian Gottlieb Fleischer Johan Bömches inasa volt 1809 és 1812 között. 1825-ben avatták mesterré, 1851-ben a céh elöljárója volt. ${ }^{50}$ Kőszeghy a K:284 „CGF” és K:285 „GoFleischer” mesterjegyekkel számos munkáját ismertette. ${ }^{51}$ Ezek közül Gyár- fás is utalt egyre-egyre és lerajzolta a jegyeket is, de azok rajza, és a velük együtt közölt próbajegyek rajza is, eltér a Kőszeghynél közöltektől ${ }^{52}$ Valószínúleg Kőszeghy jegyei a pontosabbak, de 2000-ben a mükereskedelemben volt hat, bütykös végü nyéllel készült evőkanál K:138 próbajeggyel, melyeken a K:285 mesterjegy olyan változata volt (éles sarkokkal vágott téglalap keret), mely közelebb volt a Gyárfásnál közölt 41. sz. jegyhez, mint a K:285.

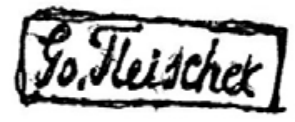

2011-ben Bécsben árvereztek el egy övet Fleischer új mesterjegyével (7. kép). ${ }^{53}$

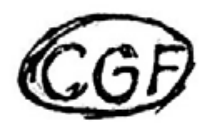

A katalógusban tévesen 1850 körülre keltezték az övet, mert azon nem az ennek megfelelő próbajegy, hanem a brassói fémjelző hivatal 1867 után használt U5 jelzése volt. Fleischer, mint tudjuk, 1888-ban halt meg, ${ }^{54}$ az övet bármikor készíthette ez előtt. Egy budapesti magángyüjteményben bütykösvégü nyéllel készített evőkanalat láttam, újabb Fleischer mesterjeggyel.

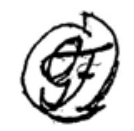

A kanálon a K:138 próbajegy mellett az 1937 után, 750 ezrelékes finomságú ezüstre használt román fémjel ${ }^{55}$ és körbe írt „, $R^{\prime \prime}$ betü is volt. Kőszeghy is említi Dr. Deutsch József áttört falú kenyérkosarát, mely 1927-ben és 1931-ben is szerepelt kiállításon. ${ }^{56}$ A kenyérkosár 1941-ben árverésen került új tulajdonoshoz, ${ }^{57}$ azóta nincs hír róla. 1928-ban a Magyar Nemzeti Múzeum bemutatta az előző tíz év szerzeményeit. Ezen a kiállításon szerepelt egy kanál Gottlieb Fleischertől. ${ }^{58}$ Ez a kanál jelenleg is a Magyar Nemzeti Múzeumban található. ${ }^{59}$ Láttuk előbb, hogy Fleischer is készített a szász viselethez tartozó díszes övet. Nem ez az egyetlen ilyen munkája. Egy 2002-es árverésen is volt egy általa készített szász öv (8. kép). ${ }^{60}$ Szerepelt a múkereskedelemben is egyházi megrendelésre készült munkája, így budapesti árverésen egy kehely 2008-ban. ${ }^{61} \mathrm{~A}$ múkereskedelemben azonban főleg háztartási ezüstjei forogtak. 1925-ben kávéskanala, 1947-ben evőkanala. 1997-ben két-rekeszes csemegés kosárkája, 2003ban füszertartója volt budapesti árverésen. ${ }^{62}$ 


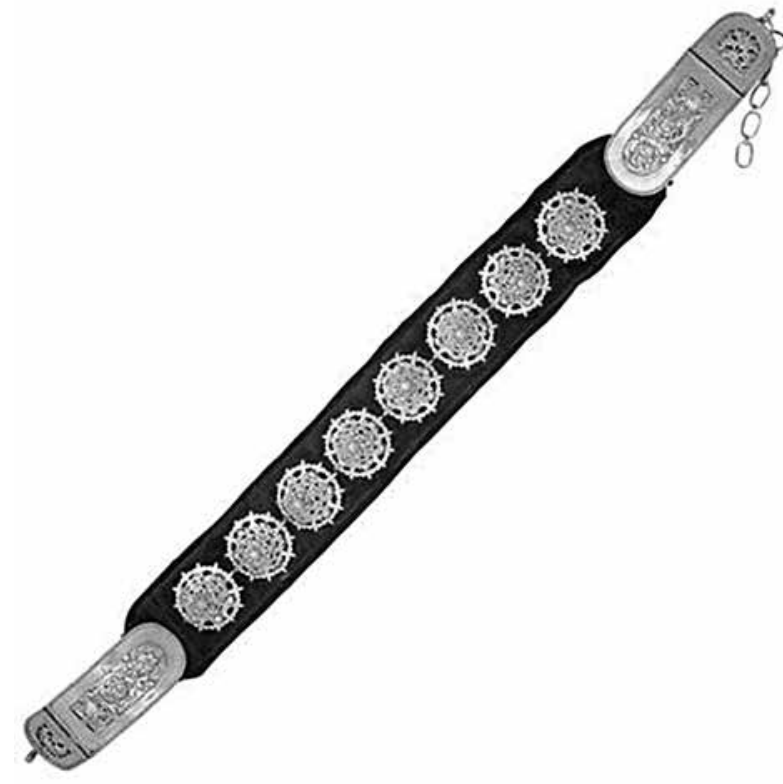

8. Szász öv.

Brassó, Christian Gottlieb Fleischer, 1830-1840 körül

Korábban láttam a budapesti múkereskedelemben egy tipikus szász övet, rajta Brassó K:133 és K:156 próbajegyével és egy kiírt, kurzív „Kasten” mesterjeggyel.

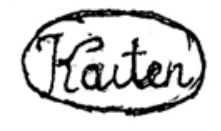

A jegy Thomas Kasten jegye lehet, aki Hanauból származott, és mint legény jött Brassóba, ahol letelepedett. 1825-ben lett mester, amikor feleségül vette Lorenz Resch senior özvegyét. Mostohafiait már ő tanította ki. ${ }^{63}$ Eddig két mesterjegyét ismertük. A nagybetűs K:286 „TK” jeggyel Kőszeghy övet ismert a kolozsvári múzeumban, füstölőt a brassói görögkeleti templomban és egy késő empire kávéskannát magángyűjteményben. Az összevont, kurzív K:287 jeggyel fogadalmi tárgyakat. ${ }^{64}$ Gyárfás Tihamér talpas poharát látta a brassói zálogházban 12-es finomsági jeggyel és a koronás-gyökér próbával. ${ }^{65}$ A kolozsvári egykori jezsuita, majd piarista templom kincstárában két érdekes votívja található. Az egyiken a Szentháromságot ábrázolta, a másikon egymással szembenálló házaspár látható. ${ }^{66}$ A budapesti műkereskedelemben volt 1991-ben egy szögletes cukordoboz, mely egykor négy lábon állhatott, de ezeket valamikor levágták. Fedelén plasztikus virág-alakú fogó volt. K:133-as koronás gyökérrel, 12-es finomsági jeggyel és Kasten K:286 mesterjegyével jelezték. Budapesti árverésen 2008-ban biedermeier cukorszórója (9. kép) és cukordoboza

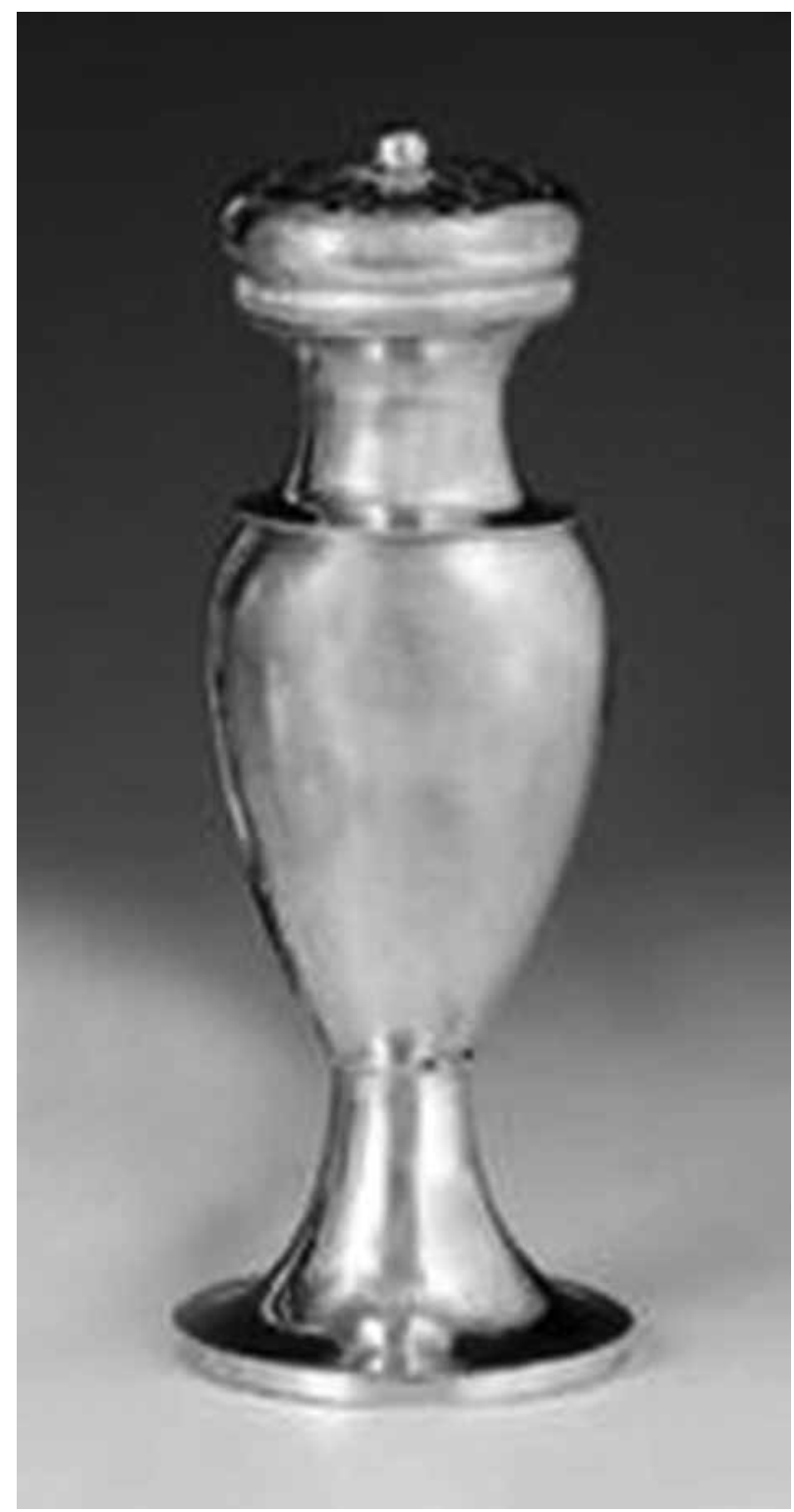

9. Cukorszóró. Brassó, Thomas Kasten, 1830 körül

(10. kép) ${ }^{67}$ 2011-ben empire sótartópárja fordult elő (11. kép). ${ }^{68}$

Ez utóbbi különösen érdekes a sótartók szárát képező fiúalakok miatt. Ezzel az öntőmintával készült sótartókról írtam már korábban. ${ }^{69}$ Akkor említettem a győri Christian Raab 1810 körül készült sótartópárját, egy Pozsony-Várteleken 1808-1809ben készült, egykor azonos készlethez tartozó sótartópárt, melynek egyikét Adamus Renner, a másikat Fridericus Becker készítette, Berthold Gelder bécsi ötvös magángyüjteményben levő párosát 1817-ből és a Dorotheum 1991-es árverésén szerepelt párosát 1815-ből. 1993-ban a budapesti mükereskedelemben volt egy sótartópár, melynek egyik felét Karl Blasius bécsi mester készítette 1807-ben, a másikat a pozsonyi Paray Károly 1835-ben, való- 


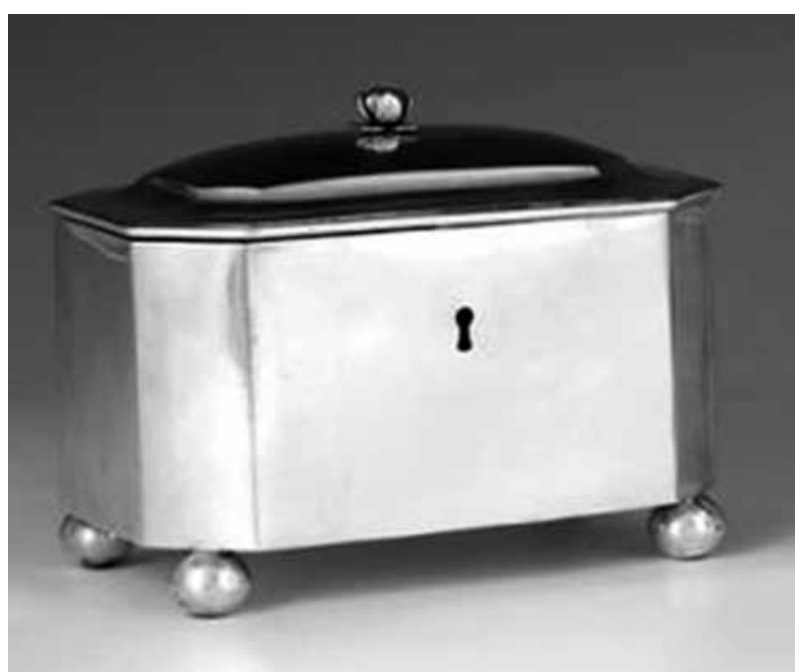

10. Cukordoboz. Brassó, Thomas Kasten, 1830 körül

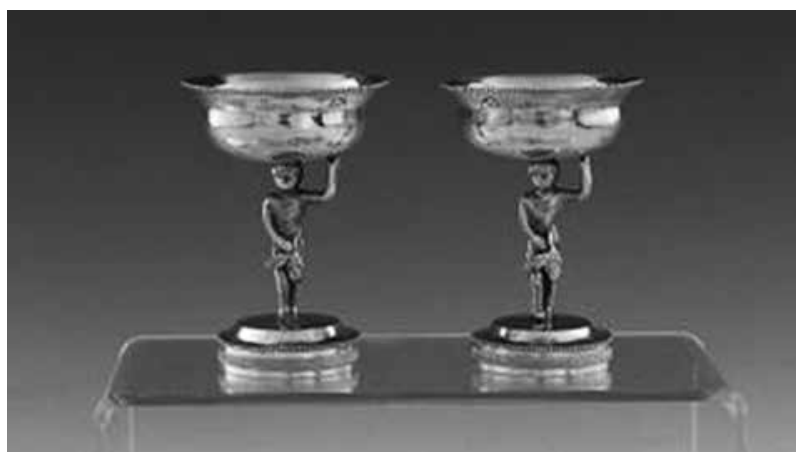

11. Fiúalakos sótartópár.

Brassó, Thomas Kasten, 1825 körül

színűleg pótlásként. Budapesti magángyűjteményben volt akkor a pozsonyi Fidelis Mayer sótartója 1806-1808-ból. A most felbukkant brassói sótartók újabb alkalmat kínálnak a tárgytípus újabban előkerült darabjainak áttekintésére. A korábbi cikk megjelenésének évében került árverésre Bécsben Berthold Gelder 1814-es sótartója, ${ }^{70}$ majd 2000-ben 1816-ban készült sótartópárja. ${ }^{71}$ A bécsi nemzetközi régiségvásáron 1997-ben (Wiener Internationale Antiquitäten Messe 1997) szerepelt Gelder 1810-es években készült fiúalakos sótartója, és egy másik is linzi próbával, kikopott mesterjeggyel. 2000-ben a budapesti múkereskedelemben volt egy fiúalakos sótartó a pesti Pasperger Ferenc mesterjegyével és a 1810-1815 között használt P évbetűvel. 2006-ban a bécsi műkereskedelemben volt egy ilyen sótartó 1810-es bécsi próbával és AK mesterjeggyel, a budapesti műkereskedelemben pedig 1807-es bécsi próbával és Ignaz Sedelmayr mesterjegyével. A szombathelyi Schmidt Múzeum kiállításán 2005ben két fiúalakos sótartópár is volt, sajnos sem a mester, sem a készítés ideje nem volt kiírva. Leg- utóbb a debreceni Villás Galéria és Aukciósház 2012-es árverésén szerepelt fiúalakos sótartó 1807es bécsi próbával, de a mester neve nem szerepelt a katalógusban. ${ }^{72}$

Christian Gust Andreas Friedrich Römer inasa volt 1812 és 1816 között. 1821-ben lett mester. A negyvenes években nem dolgozott ötvösként, ezért Adolf fiát Lorenz Reschhez szegődtette inasnak Bukarestbe. Később újra folytatta a mesterségét, mert Károly fiát már 1851 és 1856 között már maga tanította. ${ }^{73}$ Adolf Gust tehát Resch inasa volt Bukarestben 1843 és 1847 között. 1853-ban lett mester. ${ }^{74}$

Christian Gust munkáit a korábbi szakirodalom nem ismerte, Adolf Gustról is csak azt tudtuk, hogy legényremeke porcukortartó, filigrános cukorfogó és tallérból készült kanál volt, mesterremeke pedig egy ezüst lámpa és egy arany karperec. ${ }^{75}$ Kőszeghy - Gyárfás után - a brassói görögkeleti templom részére készült lámpáját ismerte. ${ }^{76}$ Jegyét azonban nem közölte, valószínüleg nem látta a lámpát, pedig Gyárfásnál szerepel a jegy rajza is, mely nagyon hasonló Adolf Gust alább ismertetendő jegyeinek rajzához. ${ }^{77}$

2006 májusában budapesti árverésen egymás után árvereztek el egy-egy erdélyi övet (12. kép). Az egyik Christian Gust, a másik Adolf Gust munkája volt. ${ }^{78}$ Az egyik övön a K:151 próbajegyhez hasonló 12-latos próbajegy és „CG” mesterjegy volt.
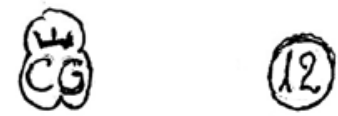

Ez Christian Gust munkája volt. A másik övön csonka „AG" mesterjegy és az előzőhöz hasonló 12 latos próbajegy volt. Mindkét övön a boglárokon 1867 és 1872 közötti 750 ezrelékes finomságot jelző fémjel utalt az utólagos fémjelzésre. Az Adolf Gustöv boglárjainak többségén feloldatlan „TD” mesterjegy is volt.

Talán Christian Gust munkája lehet egy 2010-es budapesti árverésen szerepelt sótartópár 13 latos próbajeggyel és „CG” mesterjeggyel (13. kép). ${ }^{79}$

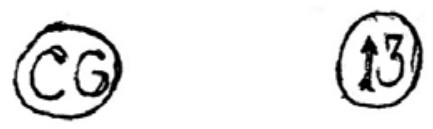

Ő lehet a mestere egy 2012-es árverésen szerepelt, kétszer beütött CG mesterjeggyel jelzett, arany karéknek is (14. kép). ${ }^{80}$

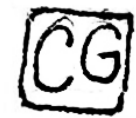


Adolf Gusttól több tárgyat is ismerek. A Gyárfásnál már közölt, téglalapba írt AG jeggyel és 13as próbajeggyel 2000-ben láttam budapesti magángyưjteményben egy kést.
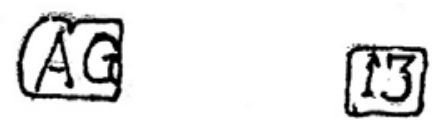

A 2001. őszi müncheni régiségvásárról (Münchener Antiquitätenmesse 2001. November) került a 2002-es tavaszi budapesti árverésre egy hasonló mesterjegyú és 12 latos próbajegyű öv, melyet a 750 ezrelékes Diana-fejes próbajeggyel, és a brassói fémjelző hivatal U5 jelével is jeleztek. ${ }^{81}$ 2013ban pedig a budapesti múkereskedelemben volt egy ehhez hasonló jegyü és 12-es próbajeggyel is jelzett szász öv.

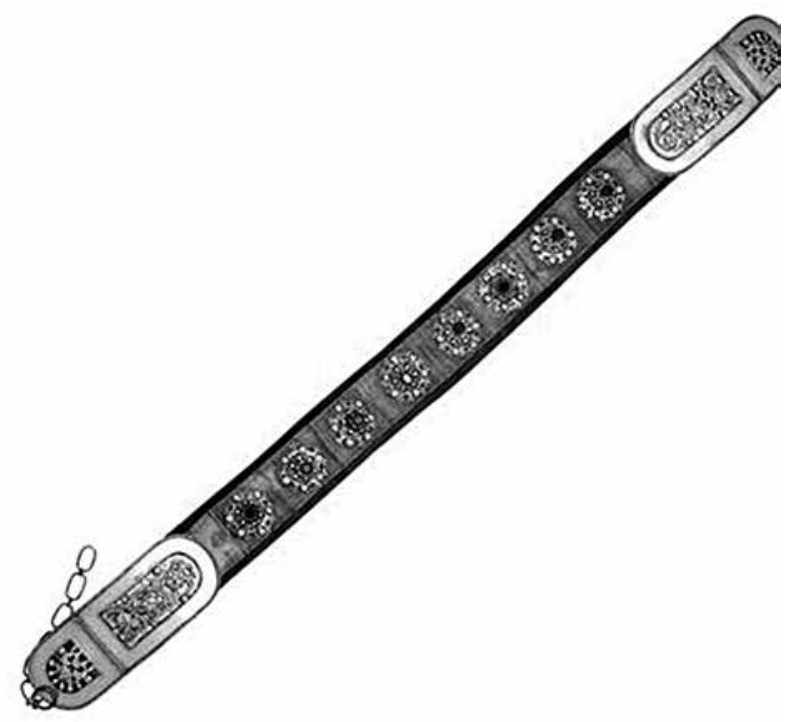

12. Szász öv.

Brassó, Adolph Gust vagy Christian Gust, 1830-1840 körül

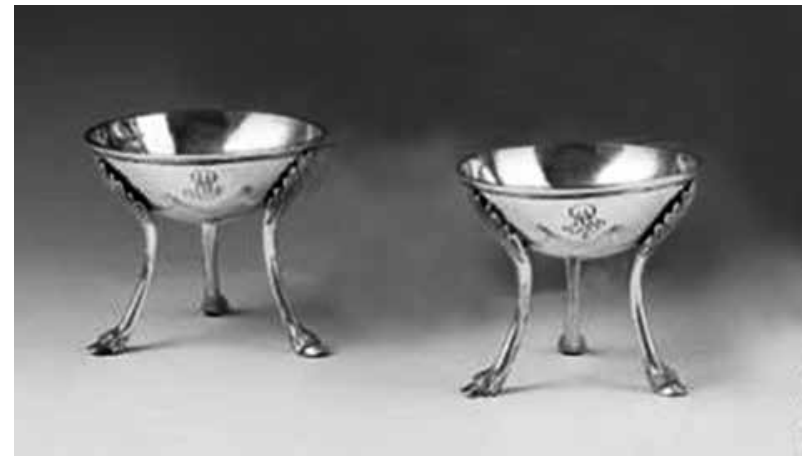

13. Sótartó pár. Brassó, Christian Gust, 1820 körül

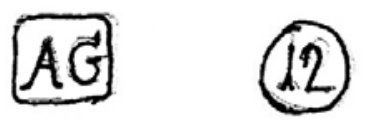

Gust egy másik, kettős keretezésű „AG” jegyével és egy új 13-as próbajeggyel láttam budapesti magángyưjteményben egy kávéskanalat.
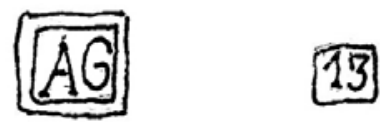

A budapesti mükereskedelemben ezzel a mesterjeggyel 2009-ben a K:134 próbajeggyel jelzett, 2012-ben pedig új 12-es próbajeggyel jelzett erdélyi szász öv bukkant fel.

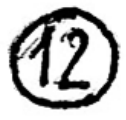

Carl Resch senior, Laurentius Resch ötvös fia, mostohaapjánál, Thomas Kastennél tanult 1831 és 1835 között. 1841. február 7-én mutatta be mesterremekét, egy ezüst kannát, arany melltüt és egy pár fülbevalót. Céhmester volt 1854-től kezdve több éven át. Inasai között találjuk fiát, Károlyt (Carolus Resch junior) is, aki 1858 és 1862 között volt a tanítványa. Felszabadulásakor legényremekét Bukarestből küldte a céhnek. ${ }^{82}$ Resch két mesterjegyét közölte Kőszeghy: a kurzív K:289, és a nyomtatott K:290 jegyet. Az elsővel a feketehalmi evangélikus egyház kelyhét, kannákat és asztali ezüstöket, a másikkal asztali ezüstöket ismert. ${ }^{83} \mathrm{Az}$ első jegy rajzát Gyárfás is közölte, a másodikra csak szövegben utalt, melyet a brassói belvárosi román templom egyik patenáján és egy nagyszebeni magángyüjtemény kancsóján látott. ${ }^{84}$

Resch gyakori szereplője a műkereskedelemnek is. A K:289 mesterjeggyel és K:133 próbajeggyel 2007-ben empire kávéskanna (15. kép), ${ }^{85}$ 2015-ben gyertyatartópár szerepelt budapesti árverésen. ${ }^{86}$ A kávéskannán és a gyertyatartókon új, 13 latos próbajegy is volt.
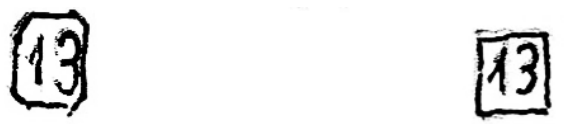

A K:289 mesterjeggyel 1998-ban budapesti magángyưjteményben láttam egy főzeléktálalót. Ezen is új próbajegy volt. 


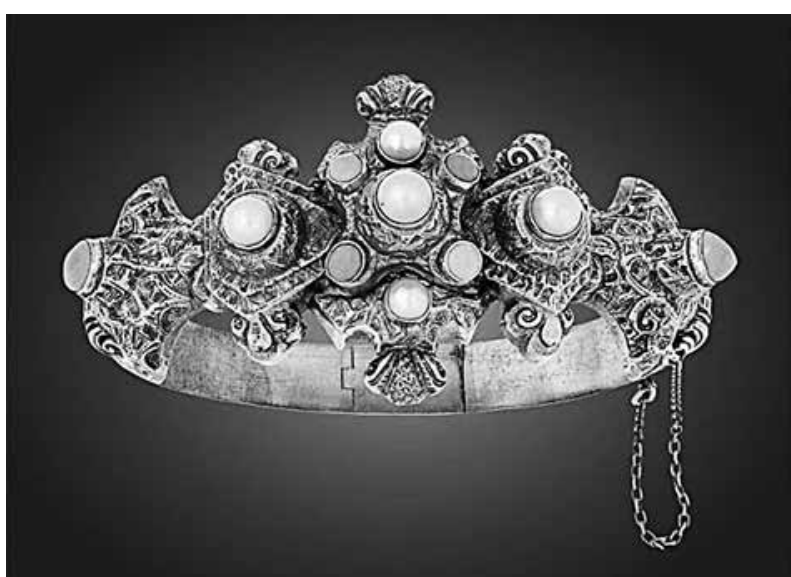

14. Karék. Brassó, Christian Gust, 1830 (?)

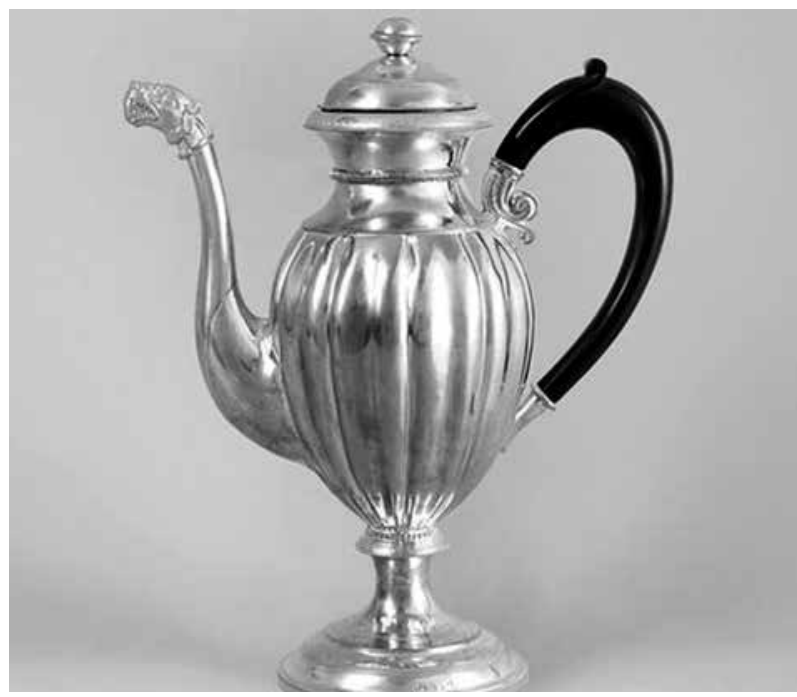

15. Empire kávéskanna. Brassó, Carl Resch, 1845

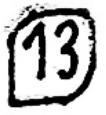

Ezt a próbajegyet egy hegedű fazonú nyéllel készült kávéskanálon a K:290 mesterjegy mellett is megtaláltam egy másik magángyújteményben. A K:290 mesterjeggyel még 1998-ban láttam budapesti magángyưjteményben egy lekerekített végü nyéllel készült kávéskanalat. Ezen új, 12 latos próbajegy volt.

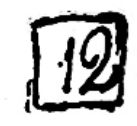

Carl Resch mesterjegyének újabb változatai is előkerültek. Egy-egy lekerekített végü nyéllel készült evőkanálon láttam a jegyeket más-más budapesti magángyüjteményben. Mindkét mesterjegyváltozat mellett új próbajegy is volt.
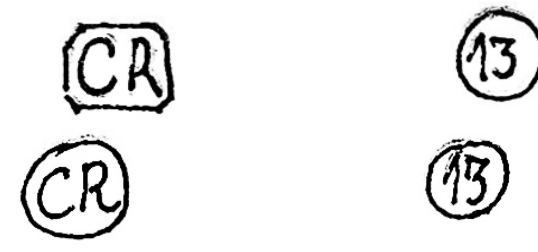

(19)

Heinrich Jekelius, Josef Jekelius brassói kereskedő fia Gottlieb Fleischernél tanult 1834 és 1838 között. 1845. augusztus 16-án nyújtotta be mesterremekét: egy kelyhet a tizenkét apostol képével, és egy arany karperecet. 1863-tól ő vezette a céh ügyeit, ő volt az utolsó céhmester. ${ }^{87}$ Kőszeghy két mesterjegyét ismerte: K:291 és K:292. Érdekes, hogy Gyárfás csak a K:291 jeggyel azonos jegyet ismerte, melyet három ezüst képen talált a brassói görög templomban, és két poháron a zálogházban. ${ }^{88}$ Kőszeghy a K:291 mesterjeggyel a brassói Miklós-templom 1847-ben készült lámpáját, a görög katolikus templom négy szentkép foglalatát, a református egyház kelyhét, patenával, és egy kávéskannát ismert magántulajdonból. A K:292 jeggyel a brassói evangélikus templomból patenát, brassói magántulajdonból evőeszközöket ismert. ${ }^{89}$ Fent már jeleztem, hogy a Josef Benckner által készített övön későbbi pótlásként ő készítette a csatoló lánc karikáját. De ő maga is készített ilyen övet. 2001-ben a budapesti mükereskedelemben volt egy öv, melynek egyik csatján 1916-os ajándékozási véset volt. A jegye új típusú keretezéssel készült, kétszer beütött $\mathrm{HJ}$ volt.

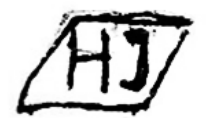

Magángyüjteményben láttam K:291 mesterjegygyel és K:139 próbajeggyel, lekerekített végü nyéllel készült kávéskanalát. Egy másik magángyưjtemény hegyes végű nyéllel készült evőkanalán K:292 mesterjegy és K:157 próbajegy mellett az 1872 utáni agárfejes fémjel is volt, benne a kolozsvári fémjelző hivatal „U” betűjelével. A mükereskedelemben 1997-ben áttört szárú cukorfogója, ${ }^{90}$ 2006-ban biedermeier kávéskannája bukkant fel (16. kép). ${ }^{91}$

Eduard Schnell Carl Muschaleknél tanult 1836 és 1840 között. Legényremeknek hat filigrános kávéskanalat, mesterremeknek szépen kidolgozott lámpát készített. 1848-ban lett mester. Gyárfás több övét és mellboglárját ismerte, de mesterjegyét csak mint írt vagy nyomtatott betưkkel készített ES jegyként említi, rajzát nem közli. ${ }^{92}$ Ugyanígy Kőszeghy is csak megemlíti, hogy a $\mathrm{K}: 293$ jegy, nyomtatott „ES” betűk, egy 1861-ben készült, K:157 próbajegygyel jelzett oltári feszületen volt a kolozsvári evangélikus templomban. ${ }^{93} \mathrm{~A}$ műkereskedelemben több 


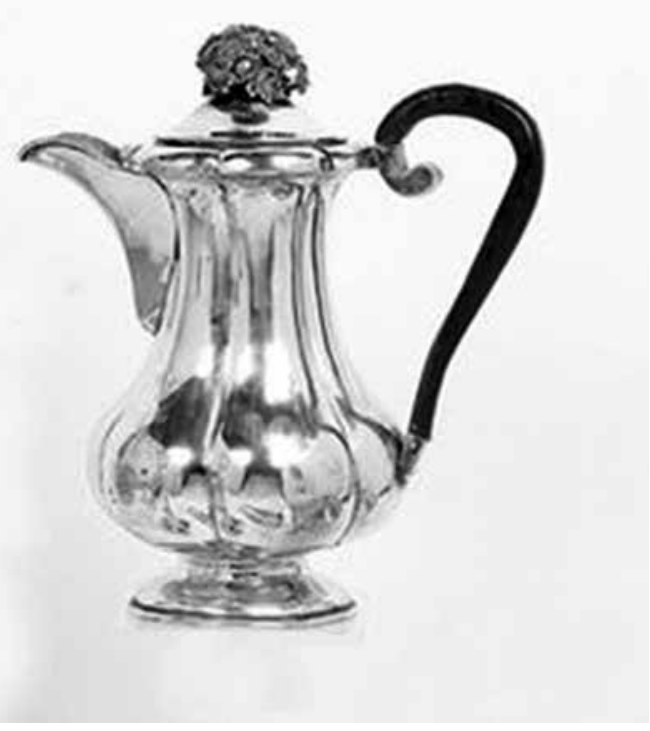

16. Kávéskanna. Brassó, Henrik Jekelius, 1850

öv is viselte jegyét. 1989-ben egy 10 bogláros öv szerepelt egy budapesti árverésen, ${ }^{94}$ 2004-ben és 2006ban egy-egy övön a K:138 próbajegy mellett kurzív volt Schnell mesterjegye.

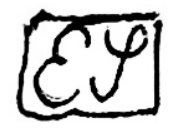

2003 márciusában egy budapesti magángyüjteményben háromlábú sótartón újabb jegyváltozat került elő: kétszer beütött kurzív ES.

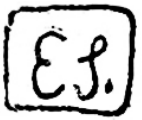

A sótartón próbajegy nem volt.

\section{Brassó?}

A budapesti mükereskedelemben volt 2015-ben egy tojástartó, összevont TK mesterjeggyel és a K:135 12-es próbához hasonló alakú, de 13-latos próbajeggyel.
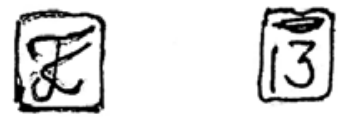

Ezzel a jegykombinációval hegyes végű nyéllel készült evő- és kávéskanalat ismerek budapesti ma- gángyüjteményekben. Talán ezek is Kasten munkái, de bizonyosak csak akkor lehetnénk, ha a próbajegy más brassói ötvös mesterjegyével is előkerülne.

Budapesti magángyűjteményben láttam egy bütykösvégü nyéllel készült evőkanalat. Rajta kopott, a fenti „Kasten” jegyhez nagyon hasonló kiírt, kurzív „Kasten” mesterjeggyel és egy különös próbajeggyel.

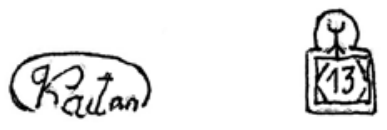

Lehet ez is brassói munka?

2011-ben a budapesti mükereskedelemben nagyméretű levesmerő bukkant fel brassói K:132 próbajeggyel, román fémjellel és kétszer beütött RG mesterjeggyel, melyet az ismert brassói mesterek nevére nem sikerült feloldani.

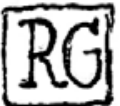

Hasonlóan problematikus egy budapesti magángyưjiteményben 2000-ben látott hegedű fazonú nyéllel készült, 1860 körülre keltezhető evőkanál meghatározása. Brassói jegyekhez (pl. K:139) hasonló próbajeggyel jelezték, mesterjegye negatív VL keretezés nélkül beütve.

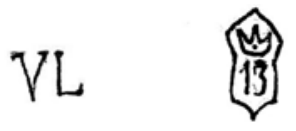

Ennél is érdekesebb egy lekerekített végü, a merítőre gyémántmetszéssel felfutó nyéllel készült evőkanál, mely a fent említett, Lucas Römer K:261 mesterjegyével és új brassói próbajeggyel jelzett evőkanállal teljesen azonos kivitelü, mindkettő egy időben került 2003-ban a jelzett magángyűjteménybe. Ez a kanál is formai okokból a 18. század végére keltezhető, de egyetlen jegye negatív EE betúk korona(?) alatt, keretezés nélkül beütve.

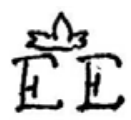

\section{Debrecen}

2015-ben a budapesti műkereskedelemben bukkant fel egy hegyes végű nyéllel készült kávéskanál Deb- 
recen K:569 próbajegyével és kopott „LL” mesterjeggyel.

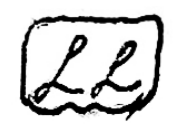

A jegy Lőrincsák László jegye lehet, akinek a Széchenyi utcai Degenfeld-házban volt forgalmas ékszerüzlete, aranyműves műhelye. Özvegye őrizte a 19. század elején megszűnt debreceni ötvöscéh ládáját, és nála másolták le a céh 1598. évi törvényeit, melyek a Történeti Tárban jelentek meg 1888-ban. ${ }^{95}$

\section{Eperjes}

Elias Kéler eperjesi ötvösmesterrel először 1991-ben foglalkoztam egy akkor előkerült újabb mesterjegye ürügyén. Ismertettem az addig ismert négy mesterjegy-változatot és az azokkal jelzett tárgyakat is. ${ }^{96}$ $\mathrm{Az}$ újabb alkalmat egy újabb mesterjegy-változat és az azzal együtt megjelent új típusú próbajegy jelentette, amit szintén összekapcsoltam az újabban előkerült tárgyak ismertetésével is. ${ }^{97}$ Most is újabb mesterjegy változatok felbukkanása ad alkalmat Elias Kéler munkásságának ismertetésére. Az első jegyváltozat egy késnyélen került elő, de az eperjesi próbajegy helyett csak a K:632 kiegészítő jegy kíséretében.

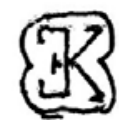

A másik jegynél, mely egy hegyes végü nyéllel készült evőkanálon került elő, csak valószínúsíthető, hogy Kéler jegye, mert csak egy új 13-as finomsági jegy kísérte.
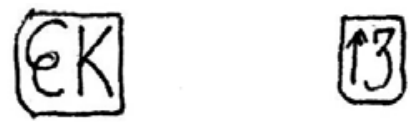

Kerültek elő új próbajegy-változatok is, mégpedig a K:621, 1821-es évszámú jeggyel azonos formájú, de 1823-as, illetve 1824-es évszámmal magángyűitemények egy-egy hegyes végű nyéllel készült evőkanalán. Ugyanez az 1824-es próbajegy volt egy németországi árverésen felbukkant tejeslábason is. ${ }^{98}$ A legérdekesebb, hogy a budapesti műkereskedelemben egy - a merítőre gyémántmetszésú nyéllel felfutó - evőkanálon, melyen Szakmáry Pál K:640 mesterjegye és a 18. század második harmadára keltezhető $\mathrm{K}: 617$ próbajegy volt, „B” évbetűt is ütöttek. Eperjesről eddig nem voltak évbetük ismertek. Árverési katalógusok átnézése során találtam egy 1985-ös katalógusban két érmes kanalat, melyet Elias Kéler munkájaként határoztak meg. ${ }^{99}$ Sajnos, a jegyeket nem közölték. Ez a tárgytípus eddig nem volt ismert Kélertől.

Még 1999-ben közöltem Matheides Gusztáv mesterjegyét egy új típusú próbajeggyel együtt. A meghatározást arra alapoztam, hogy az egy olyan sótartópár egyikén szerepelt, amelyik másikén Eperjes K:620 próbajegye és Gottfried Kéler K:654 mesterjegye volt. ${ }^{100}$ Most előkerült egy lekerekített végű nyéllel készült kávéskanál egy budapesti magángyüjteményben a közölt mesterjegynél jobb tartású „MG” mesterjeggyel és új, 13-as próbajeggyel.
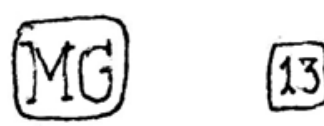

\section{Lőcse}

2008-ban New Yorkban a Sotheby's egy 1570 körülre keltezett serleget, valószínűleg egy kettős serleg egyik felét, árverezett el (17. kép). ${ }^{101} \mathrm{Az} \mathrm{Ot}$ to Pick gyüjteményből származó serlegen, a leírás szerint, mesterjegyként egy kancsó, próbajegyként ún. „Hausmarke” volt. Ezzel az árverező nem tudott semmit sem kezdeni. Szerencsére sikerült megszerezni a jegyeket. A próbajegy Lőcse K:1138, 1600 körülre keltezett próbajegye, a mesterjegy egy kancsó volt.

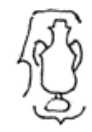

A jegy lehet ún. „beszélö” jegy, ami a tulajdonos nevére utal. Például az augsburgi Michael Hafner (működött 1665-1700) jegye egy cserépedény. ${ }^{102}$ Azonban lehet, hogy a névnek semmilyen kapcsolata nincs a jegy alakjával. A nürnbergi Jacob Frölich (működött 1555-1579) jegye címerpajzsban hasas korsó. ${ }^{103}$ Gondolhatnánk, tekintve Lő́cse német kapcsolatait, hogy a két család leszármazottja jutott el Lőcsére. A Fröhlich családnév már 1600ban megjelent Lőcsén, de ilyen nevű ötvöst nem ismerek. A Hafner családnév viszont nem fordult elő Lőcsén. ${ }^{104}$ Mivel az a lehetőség, hogy a nürnbergi Frölichhez hasonlóan a lőcsei ötvös nevének sincs semmi köze a jegyben ábrázolt korsóhoz, gyakorlatilag járhatatlan. Marad az, hogy keresünk olyan lőcsei ötvöst, akinek neve kapcsolatba hozható a korsós jeggyel. Toranová 1982-ben em- 


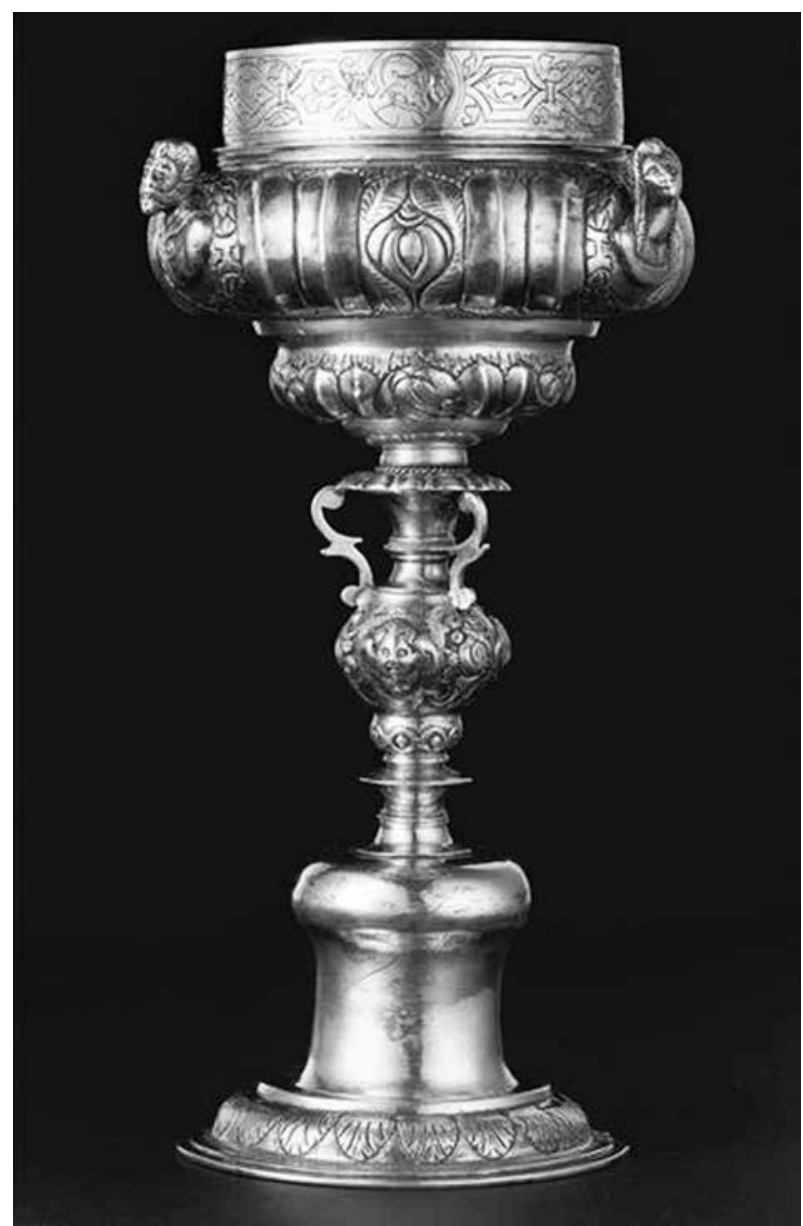

17. Serleg. Lőcse, Elias Kreuchel?, 17. sz. vége

lített egy Samuel Mäss (Mész, Moesz), 1697-1710 között szerepelt lőcsei ötvöst, ${ }^{105}$ akinek neve emlékeztethetne a Maß = mérték, véka, pint szóra. Ezzel csak az a baj, hogy nem löcsei, hanem kassai ötvös volt. ${ }^{106}$ Toranová korábbi közleményében nem is szerepelt. ${ }^{107} \mathrm{~A}$ másik lehetőség Elias vagy Eusebius Kreuchel (Krichl, Kraiczel, Krychel, Krückl), aki 1711 és 1748 között működött. ${ }^{108} \mathrm{Ne}-$ vében talán a söröskorsó jelentésű bajor-osztrák Kriegl, Krügel szó ismerhető fel. ${ }^{109}$ Elias Bernhard Kreichel 1711. július 8-án vette feleségül a 29 éves Susanna Praetoriusint, ${ }^{110}$ aki már terhes volt első gyermekükkel. Három leányuk és két fiúk született. ${ }^{111}$ Friedrich Hiob 1744-től apjánál volt inas, azonban már Szilassy Jánosnál szabadult fel 1748-ban, ${ }^{112}$ valószínúleg apja halála miatt. Az anya, Susanna Praetoriusin 1759. április 26-án halt meg. ${ }^{113}$ Friedrich Hiob Kreuchel Golschmied 1751. május 25-én Maria Elisabethát vette feleségül. ${ }^{114}$ Legidősebb leányuk, Anna Mária 23 évesen 1775. november 7-én, Friedrich Hiob Kreuchel 1785. április 11-én halt meg. ${ }^{115} \mathrm{Az}$ idősebb fiú valószínüleg elkerült Lőcséről. Úgy gondolom, hogy, annak ellenére, hogy a fent említett kupa stílusa alapján jóval korábban is készülhetett, mestere Elias Bernhard Kreuchel lehetett. Talán a további kutatás, némi szerencsével, bizonyosságot hozhat.

\section{Nagyvárad}

Budapesti magángyưjteményben láttam egy lekerekített végű nyéllel készült evőkanalat Nagyvárad K:1538, 1850 körülre keltezett próbajegyével és „SI” mesterjeggyel.

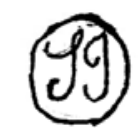

A jegy Simon Izsák jegye lehet, akit 1828-ban Várad-Várallya mezővárosban írtak össze, ahol egy legényt is alkalmazott. ${ }^{116}$ További adatot nem találtam róla.

2013-ban mutattam be a Pesten 1871-ben meghalt, Becskereken született Kamody Mihályt, akinek nagyváradi próbajeggyel és „KAMODY” mesterjeggyel készült evőkanalát, és szintén nagyváradi próbajeggyel, de összevont „MK” betükkel jelzett bütykösvégű nyéllel készült kávéskanalát is közöltem. ${ }^{117}$ Akkor nagyváradi múködésére, a jelzett tárgyakon kívül, semmilyen adat nem állt rendelkezésemre. Nemrég az 1848/49-i Minisztériumi Levéltárban, a Honvédelmi Minisztérium Általános iratok (H75) anyagában ${ }^{118}$ Kamodi Mihály Nváradi arany s' ezüstmíves (lakik Zöldfa-utca 23. sz.a. a Geiszt-házban) 1849. július 13-án kelt, a Hadügyi Tanácsnoknak címzett beadványa került elő, ${ }^{119}$ melyben előadja, hogy a Német Légió, újabban 126. számú honvéd zászlóalj részére rendelt csákó-rózsákat elkészítette, számadását leadta és kéri 156 ezüst forint, 40 krajcár követelésének kifizetését. 1849. július 26-án a Hadügyi Tanácsnok a zászlóalj parancsnokságának továbbította a kérelmet, mivel nem a minisztérium rendelte meg a csákó-rózsákat és kéri az ügy helyileg történő tisztázását. ${ }^{120} \mathrm{~A}$ dátumokat látva kétséges, hogy Kamody megkapta a pénzét, de nagyváradi működését így már nemcsak a kanalak próbajegye igazolja.

\section{Rimaszombat}

1997-ben sikerült meghatározni 1833-as próbajeggyel Kolmajer Sámuel junior mesterjegyét. ${ }^{121}$ Kolmajer Sámuel apjánál, az idősebb Kolmajer Sámuelnél volt inas 1822-től. ${ }^{122}$ 1832-ben készítette el 
remekét: 1 pár arany fülbevalót, 1 arany gyürüt és 1 pár ezüst sótartót. ${ }^{123}$ Négykaréjos keretbe foglalt mesterjegye azóta többször előfordult hasonlóan keretezett 13-as próbajeggyel.

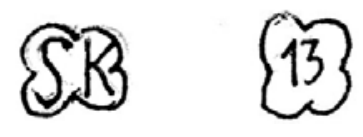

Ezekkel a jegyekkel filigrán gombja található a Szlovák Nemzeti Múzeumban, ${ }^{124} 2002$ decemberében főzeléktálaló, 2013. januárban öt kávéskanál volt budapesti magángyűjteményekben. Ô 1833-ig szerepelt a céh irataiban. ${ }^{125}$

Az idősebb Samuel Kolmajert 1789 és 1825 között említették. Remekét 1790-ben készítette el. 1801 és 1812 között hétszer dékán, 1813-1815 között céhmester volt. Inasa volt - fián kívül - a későbbi rimaszombati mester, Hudiczius József. ${ }^{126}$ Működési idejét tekintve az eddig említett tárgyak egyike sem lehetett a munkája. Egy budapesti árverésen azonban felbukkant egy sótartó, próbajegy nélkül, de mesterjeggyel (18. kép). ${ }^{127}$

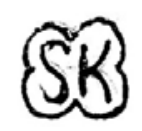

A sótartó stílusa alapján csak az idősebb Kolmajer Sámuel munkája lehet. Sajnos, a 17. század és a 19. század tízes évei között eddig nem került elő rimaszombati próbajegy.

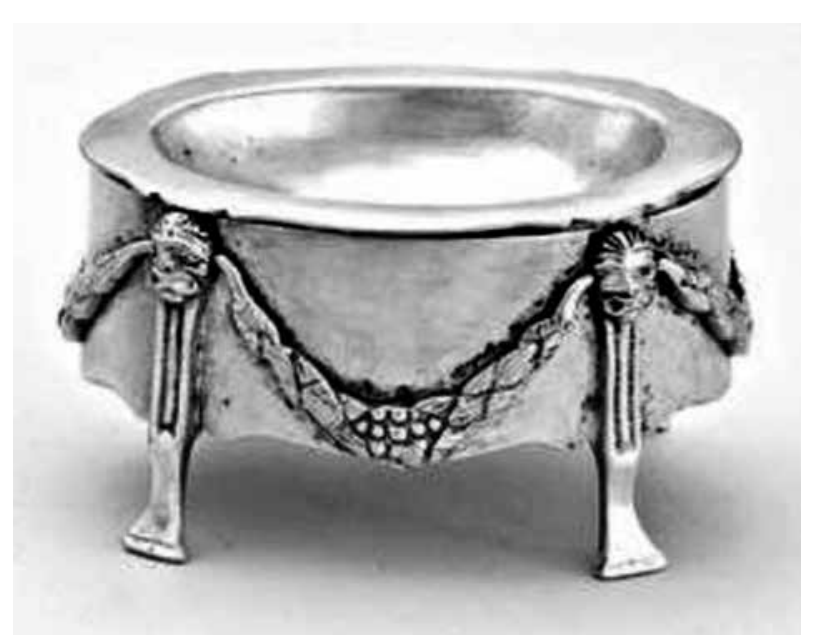

18. Füszertartó.

Rimaszombat, Samuel Kolmajer sen., 19. sz. eleje

\section{Rimaszombat?}

2011 decemberében budapesti árverésen jelent meg egy talpas pohár különös mesterjeggyel. ${ }^{128}$

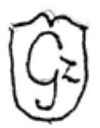

A jegyet a katalógus „GZ” alakban értelmezte, de a különös arányok miatt, ez nyilvánvalóan téves. Felmerült az ötlet, hogy "kétszintes” jegy lehet, vagyis "Cz/J" alakban értelmezendő. ${ }^{129} \mathrm{Ez}$ valószínúleg magyar nyelvü környezetre utal. Feltételezem, hogy a jegy a rimaszombati Csetneki János jegye, aki 1627 körül működött. ${ }^{130}$ (A névbetűk alapján az ugyancsak rimaszombati Csontos István is szóba jöhetne, aki 1649-1668 között működött, de az ő jegye ismert a céhládáról. ${ }^{131}$ Megjegyzem, az itt szerepelt jegyek között több is „,kétszintes”.)

\section{Szabadka}

A Mecklenburg hercegségi Schwerin városából származó Joannes Christianus Parbs aurifaber 1830ban kötött házasságot Pesten, a Terézvárosban. Fiát már Szabadkán keresztelték 1831-ben. Kiírt „Parbs” mesterjegyét „A" évbetü és a szabadkai próbajegy mellett korábban már közöltem. ${ }^{132}$ Egy budapesti magángyűjteményben egy 1833-as 20 krajcáros érmével készült kanálon „, $\mathrm{A}^{\prime}$ évbetû mellett a szabadkai városjegy csonka vagy kopott alakja és Parbs új „JP" mesterjegye jelent meg.

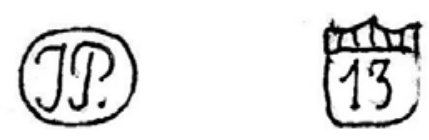

Lehet persze, hogy a próbajegy nem csonka vagy kopott, hanem egy új jegyváltozatot képvisel. Ezt további tárgyak előkerülése döntheti el.

\section{Szatmárnémeti}

A Szatmárnémetiben működött Jurasko J. mester kiírt mesterjegyét és „JJ" monogramú jegyét közöltem korábban, de a keresztnevét azóta sem sikerült megismerni. ${ }^{133}$ Egy budapesti magángyüjteményben a kiírt "JURASKO” jegy mellett Szatmárnémeti új típusú próbajegyét találtam egy lekerekített végü nyéllel készült evőkanálon. 
nyéllel készült evőkanalán Jurasko „JJ” mesterjegye mellett.

Sajnos a jegy évszámának harmadik jegye kopás miatt nem volt kiolvasható, így az évszám csak $18 \times 2$ alakban adható meg. Hasonló jegyet már korábban is láttam a budapesti múkereskedelemben egy cukordobozon. Ezen a mesterjegy teljesen olvashatatlanná kopott, a próbajegy is alig látszott, olvasata talán 1842 lehetett. Ujabb próbajegy-változat jelent meg egy budapesti magángyűjtemény lekerekített végü

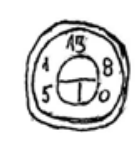

Ennek évszáma jól olvashatóan 1850 volt. Ugyanezeket a jegyeket már korábban is láttam egy főzeléktálalón a budapesti múkereskedelemben. Jurasko J. mester egy 1870-ben kiadott címjegyzék szerint már Nagybányán működött. ${ }^{134}$ Sajnos a keresztneve ebből sem derült ki.

\section{JEGYZETEK}

1 Kốszeghy Elemér: Magyarországi ötvösjegyek a középkortól 1867-ig. Budapest 1936.

2 P. Brestyánszky Ilona: A pest-budai ötvösség története. Budapest 1977.

3 Grotte András: Kísérlet néhány magyarországi ötvösjegy feloldására XIII. Művészettörténeti Értesítő LX. 2011, 107.

4 Köszeghy i. m. 80.

5 Földes Emilia: Ötvöskatalógus. Budapest 1978. 417. sz. Pecsétgyưrű. A szélesedő abroncs fej felé eső részén fekete zománc alapon romantikus vésett arany virág ornamentika. Az ovális gyűrűfej foglalatában opálkőre erősített, balra néző férfiportré.

6 Óra- és Ékszerkereskedelmi Vállalat 1984. Őszi ékszer- és nemesfém aukció (1984. november 27.) 1. sz.: Férfi levélzáró gyưrü, antik arany, öntött, vésett, a nyolcszögű fejre felfutó széles plasztikus rózsákkal díszített sín, a fejen vésett családi címer. Pest, 1830 körül. Thiel Károly (?) Súly 15,4 g, kopott.

7 István Heller: Ungarische und siebenbürgische Goldschmiedearbeiten. München 2000, 52 und Markentafel 51.

8 Kőszeghy Testoryt és Thiel Keresztélyt nem ismerte, Thiel Károly működését 1811-1828 között adta meg. Brestyánszky és Horváth Henrik (A pesti arany- és ezüstmívesek névsora. Budapest Régiségei. Régészeti és történeti évkönyv XII. 1937, 257) 1811 és 1839 között említi, holott 1829-től (Heller i. m. 137) már az özvegy, egy legény segítségével, vezette a műhelyt.

9 Pest-Belváros születési anyakönyvei. Magyar Nemzeti Levéltár, Országos Levéltár (továbbiakban: MNL OL), Filmtár A74 sz. doboz.

10 Aloysia (1814. október 19. - 1816. október 29.), Clara Helena (1821. október 11.), Amalia Hermina (1822. november 29.), Justina Theresia (1826. október 8.) és Mathildis Karolina (1828. március 27.). Pest-Belváros születési anyakönyvei, MNL OL, Filmtár A75 sz. doboz, Pest-Belváros halálozási anyakönyvei MNL OL, Filmtár A89 sz. doboz.

11 Pest-Belváros halálozási anyakönyvei. MNL OL, Filmtár, A89 sz. doboz.

12 P. Brestyánszky i. m. 376.

13 Uo. és Horváth Henrik i. m. 257.
14 Pest-Deáktéri evangélikus gyülekezet halotti anyakönyvei. MNL OL, Filmtár, A4 sz. doboz.

15 P. Brestyánszky i. m. 376.

16 Pest-Belváros halotti anyakönyvei. MNL OL, Filmtár, A90 sz. doboz.

17 Pest-Deáktéri evangélikus gyülekezet születési anyakönyvei. MNL OL, Filmtár A2 sz. doboz.

18 Pest-Belváros házassági anyakönyve. MNL OL, Filmtár A82 sz. doboz.

19 Pest-Deáktéri evangélikus gyülekezet halotti anyakönyvei. MNL OL, Filmtár A2 sz. doboz.

20 Horváth Henrik i. m. 257. Kapossy János: Magyarországi ötvösök a XVIII-XIX. században. Budapest 1934 (továbbiakban: Kapossy 1934), 46.

21 Pest-Belváros születési anyakönyve. MNL OL, Filmtár, A76 sz. doboz.

22 Grotte András: Kísérlet néhány magyarországi ötvösjegy feloldásra III. Művvészettörténeti Értesítő XLIV. 1995, 118; Uö: Kísérlet néhány magyarországi ötvösjegy feloldásra VII. Művészettörténeti Ertesítő L. 2000, 135; Uố: Kísérlet néhány magyarországi ötvösjegy feloldásra XIV. Múvészettörténeti Ertesítő LXII. 2013, 67; Uố: Kísérlet néhány magyarországi ötvösjegy feloldásra XV. Művészettörténeti Ertesítő LXIII. 2014, 144.

23 Grotte András: Kísérlet néhány magyarországi ötvösjegy feloldásra XVI. Művészettörténeti Értesítő LXIV. 2015, 177.

24 Pest-Belváros házassági anyakönyvei. MNL OL, Filmtár, A85 sz. doboz.

25 P. Brestyánszky i. m. 347.

26 Uo.

27 BÁV 50. Művészeti Aukció (2007. május 22.) 232. sz.: Női gyứrű, $14 \mathrm{~K}$ arany, caul fazon egy almandin díszítéssel, Pest 1860 körül, súly 5,6 g, átm.: 19,3 mm, kopott.

28 P. Brestyánszky i. m. 347.

29 Gyárfás Tihamér: A brassai ötvösség története. Brassó 1912 (továbbiakban: Gyárfás 1912), 118.

30 Uo. 316, 17. sz. jegy, Kőszeghy i. m. 42.

31 Sotheby's New York, April 16, 1997. Important English and Continental Silver. 73.: A Hungarian silvergilt, enamelled and stone-set morse, of circural domed form, mounted with numerous turquoises, pearls and 
other stones and enamelled with shaded tulips and other flowers, the back engraved with two concentric wreaths. Maker's mark only, AG, probably for Andreas Gorgias of Brassó, circa 1675, diameter $13 \mathrm{~cm}$.

32 Gyárfás 1912, 128.

33 Gyárfás Tihamér: Brassai ötvösmüvek. Archaeologiai Értesítő. Ujj Folyam XXX. 1910 (továbbiakban: Gyárfás 1910), 233.

34 Az Országos Magyar Iparművészeti Múzeum Régi ezüst kiállításának leíró lajstroma (Szerk. Csányi Károly) Budapest 1927 (a továbbiakban: Kiállítás 1927), 402. Nagy, nyolcszögü pohár, kihajló kis talppal, aranyozott, oldalán poncolt alapon barokk arabeszk (Laub- und Bandelwerk) dísz. Jellegzetes erdélyi alak. M. 18,5 cm. AM mesterjegy. Erdély, 18. sz. e. (kiállító: Gróf Andrássy Géza); Erdély régi művészeti emlékeinek kiállítása az Iparmúvészeti Múzeumban. Budapest 1931 (továbbiak ban: Kiállitás 1931), 144.: Nagy, nyolcszögü pohár. Aranyozott ezüst. Oldalán poncolt alapon barokk arabeszk (rácsos rozettás és szalagos, indás, leveles és gyümölcsös) dísz. AM betűs jegy. M: 18,5 cm. Brassó, 18. sz. eleje. Képe: III. tábla (kiállító: Gróf Andrássy Géza).

35 BÁV 45. Művészeti Aukció (2004. október 27.) 713. Erdélyi érmes pohár. Ezüst, 323 gr, belül, illetve talp- és szájperemén tüzaranyozott. Kerek talpon ívelt és hullámos oldalakkal tagolt hatszögletü edénytest. Palástján befoglalt érmek: Lipót főherceg tallér (1621), I. Lipót császár tallér (1696), II. Péter cár rubel (1729) és alján egy keresztelő érem: Paul Walther, Drezda (1635-1644). Szájpermén és talp fölött kontúr-beütött régence-motívumok. Tulajdonosi vésett: egybe fonódó „BE” monogram. Jelzett: Brassó, 1730, Andreas Mauthner (szájperemen kettőzve), Köszeghy i. m. 257 variáns. M: 13,5 cm.

36 Gyárfás 1912, 130.

37 Uo. 289,2.

38 Az Ernst-Múzeum Aukciói XXI. (1922. november) 1197.: Két sótartó, napraforgó alakú levelekkel. LR (lucas Römer) mesterjegy. Brassó, empire.

39 Galerie Jürg Stuker, Bern (Schweiz), Auktionen 180-189. Bedeutende schweizer Nachlässe. (23. November 1979.) 2966.: Salzgefäss, Kronstadt, um 1735. Meistermarke Lucas Römer. Tiefgemuldete Ovalform mit oben doppelt geschwungener Scheidewand, auf vier geschwungenen Spachtelfüssen. Innen vergoldet. $8 \times 5 \times 5,5 \mathrm{~cm}$. Gewicht $60 \mathrm{~g}$.

40 Gyárfás 1912, 132.

41 Kiállítás 1931, 85.: Fedeles kupa. Ezüst, részben aranyozott. Pillérekkel tagolt, hasábos testtel és fedővel. Tetején orsós, gerezdes gomb, kagylódíszes billentővel és akantuszleveles füllel. IB mesterjegy (Joseph Benckner), M: 26 cm, Brassó, 1720 körül. Kiállító: Tószeghy Richárd.

42 Budapest, Magyar Nemzeti Múzeum, ltsz. 1949.320. Mađarsko zlatarstvo od X do XIX veka. Beograd-Zagreb. oktobar-novembar 1968, 162. sz.; Trésors de l'orfèvrerie hongroise du $\mathrm{X}^{\mathrm{e}}$ au XIX $\mathrm{X}^{\mathrm{e}}$ siècle. Bruxelles 1976, 161. sz.; Gold and Silver. Treasures of Hungary from the 9th to the 19th Century. Cooper-Hewitt Museum and the Smithsonian Traveling Exhibition Service. 1986, 51; Schätze des ungarischen Barock. Hanau 1991, 67.

43 Marc Rosenberg: Der Goldschmiede Merkzeichen. IV. Band. Berlin 1928, 9606 (az ismeretlen jegyek között).

44 István Heller: Ungarische und siebenbürgische Goldschmiedenarbeiten. Vom Ende des 16. Jahrhunderts bis zum Ende des 19. Jahrhunderts. München 2000, 33. Markentafeln, Nr. 32.

45 István Heller: Europäische Goldschmiedearbeiten 1560-1860. München 2003, Nr. 168.: Patronentasche. Silber, teilvergoldet, gegossen, graviert, ziseliert, punziert. Die geschwungene, profilierte Patronentasche ist mit einem gewölbtem Deckel gearbeitet. Die beiden Teilen werden durch ein Scharnier an der Längsseite des Behälters zusammengehalten. Die Dekoration der Vorderseite ist aus Kriegsgerät und Flaggen zusammengestellt. Die Umgebung ist mit C-Voluten, Rocaillen, Blumen mit Blättern und Akanthus bearbeitet auf fein punziertem Grund. Die zwei Seitenfelder und der Deckel sind mit ähnlichen Motiven ausgestattet. Auf dem gewölbtem Deckel ist ein gegossener, durchbrochen gefertigter Teil soldiert: dieser ist aus einer Maske und Tieren gebildet. Am Deckel vorn ist ein kleiner Drücker ausgesetzt. Auf der Rückseite der Patronentasche ist eine Schlaufe aus Silber ausgebracht. $13,5 \times 10,7 \times 3,7 \mathrm{~cm}, 398 \mathrm{~g}$.

46 Sotheby's London, Dr. Heller's Lexicon. Auction in London. 4. December 2012, 103. Josephus Benckner. Romanian Silver-gilt Despatch Box. Braşov (Kronstadt) circa 1760. Turkish influences, chased with military trophies, scrolls and flowers, hinged cover and belt mount. 13,8 cm, 398 gr.

47 Dr. Fischer Heilbronner Kunst- und Auktionshaus. 154. Fischer-Auktion (26. November 2005). 315.: Deckelkanne. Kronstadt. Meister Josephus Benckner, um 1730. Silber, getrieben, gegossen, punziert und partiell vergoldet. Runder, mehrfach passig geschweifter, gewölbter und abgetreppter Fuß. Entsprechend gearbeitete Wandung und gewölbter Deckel mit vertikal verlaufenden, konvexen und konkaven Furchen, durch vertikale Faltenzüge gegliedert. Oberhalb des Fußes und unterhalb der Mündung getriebenes Wellenband. Als Deckelknauf plastisch gearbeitete Figur eines Knaben: Allegorie des Sieges mit Palmenzweig und Lorbeerkranz. Lyraförmige, durchbrochen gearbeitete Daumenrast mit Muschelmotiven. In Voluten endender, gegossener Henkel mit im Hochrelief gearbeitetem Akantusblatt und seitlich Bandelwerk partiell auf fein punziertem Grund. Unter dem Boden gestempelt mit Kronstädter Beschaumarke, Meistrmarke JB und Lótigkeitszahl 13. H: 25,7 cm, 1157 g. (K:265)

48 Nagyházi Galéria és Aukciósház. Mütárgyárverés 1998. október 7. 145.: Kávéskanna. Brassó, 18. sz. közepe. Josephus Benckner (?), K:265. M: 26.5 cm, 703,9 gr.

49 BÁV. 38. Müvészeti Aukció (2001, április 26.) 497. Kávéskanna. Ezüst, 704 gr. Kerek talpon körte alakú, függőlegesen tagozott test, rövid kiöntő csővel, zsanéros tetővel, fa füllel. Javított. Jelzett, magyar vagy német, 1740 körül, J.B. feloldatlan mesterjegy.

50 Gyárfás 1912, 141.

51 Köszeghy i. m. 52.

52 Gyárfás 1912, 316 és 22. jegy, és 318 és 41.jegy.

53 Dorotheum 2290. Kunstauktion. Silber (16. Mai 2011.) 740. Kronstädter Prunkgürtel. Silber, vergoldete Schnallen sowie Montierung, rote facettierte Glassteine, Gesamtlänge $88 \mathrm{~cm}$, Meisterzeichen CGF $=$ Christian G. Fleischer, Beschauzeichen Kronstadt um 1850.

54 Köszeghy i. m. 52.

55 Jan Divis: Markenzeichen auf Silber. Prag 1976. 1601 sz. jegy, de az „A" betű helyén „U” betűvel. 
56 Kiállítás 1927, 582.: Ovális kosár, alacsony talpon nyugvó hajlott falán és kihajló peremén áttört levélindás, illetőleg virágtöves frízekkel, kengyeles füllel. Go. Fleischer mesterjeggyel. H: 25,5 cm. Brassó XIX. sz. e. - Deutsch József dr.; Kiállítás 1931, 253.: Ovális kenyérkosár. Ezüst. Oldala áttört indásdíszü. Pereme és kengyeles fogója palmettás. G. Fleischer mesterjeggyel. Átm.: $26 \mathrm{~cm}$. Brassó XIX. sz. 1. f. - Dr. Deutsch József.

57 Gróf Almásy-Teleki Éva Müvészeti Intézete (volt Ernst-Múzeum) VII. Nagy művészeti aukció. 1. Dr. D. J. úr gyüjteménye. 2. Főúri ezüst, szőnyeg és bútor. 1941. november 7. 77.: Ovális füles kosár, ezüst, empire díszítéssel. (Gottlieb Fleischer műve.) Brassó 1830 körül. 550 gr.

58 A Magyar Nemzeti Múzeum Kiállításai, V. Tíz év szerzeményei 1919-1928. (Budapest 1928) 22. Tárló. Magyar városok és ötvösök ezüstbélyegei a XVIII. és XIX. századból, nagyobbára kanalakon. 4. Brassó, Fleischer Gottlieb, XIX. sz. 1. f. (1925).

59 Ltsz.: 1925.73a. Jegyei: K:137, 285.

60 Nagyházi Galéria és Aukciósház. 92. Ezüstök és ékszerek árverése. 2002. december 3. 177 sz.: Szász öv. Brassó 1830 körül. Christian Gottlieb Fleischer (Köszeghy i. m. 138, 284), aranyozott ezüst és bordó üveg kőutánzat, bársony és paszomány, tulipános kéttagú kapocs pár és textilbe erősített nyolcréteges boglár. H: 98 cm, 949 gr.

61 Polgár Galéria és Aukciósház. 76. Tavaszi Müvészeti Aukció (2008. május 22.) 571. sz.: Brassói kehely. 13 latos antik ezüst, 772 gr, $26 \times 14,5 \mathrm{~cm}$. Brassó, 1830 körüli fémjel, Go. Fleischer (Christian Gottlieb Fleischer) mesterjegy. Aranyozott ezüst. Trébelt, karéjos talpon és a nóduszon vésett, cizellált díszítés, kehely áttört, vésett tartóban. Aranyozás kopott, talpperemén repedés.

62 A M. Kir. Postatakarékpénztár Árverési Csarnokának 1925. májusi általános aukciója (1925. május 23.). 673b.: Kávéskanál ezüstből, négy különböző darab, hazai ötvösjegyekkel: Besztercebánya, Rosenberger 1858 és 1859, Lőcse 1850 körül és Brassó, Fleischer, 1830 körül (Lehet, hogy ez azonos a Magyar Nemzeti Múzeum kanalával?); A Magyar Postatakarékpénztár Árverési Csarnokának 125. számú aukciója (1947. június 24.) 926.: Evőkanál. Ezüst, 6 darab, 384 gr. Brassó, Fleischer Gottlieb, 1830 körül; BÁV. 30. Müvészeti Árverés (1997. március 9.) 340.: Csemegés kosárka két-rekeszes. Ezüst, filigrán, 274 gr. Christian Gottlieb Fleischer. Brassó, 1830 körül (Köszeghy i. m. 138, 285); Nagyházi Galéria és Aukciósház. 96. Bútorok, órák, ékszerek és ezüstök árverése (2003. május 15.). 222.: Fűszertartó. Brassó 1830 körül. Christian Gottlieb Fleischer (Köszeghy i. m. 138, 284). 12 latos antik ezüst, aranyozás nyomával, plasztikus leveles ágon mélyöblü, sziromszegélyes kerek tálka. M: $6 \mathrm{~cm}, 81,7 \mathrm{gr}$.

63 Gyárfás 1912, 141.

64 Köszeghy i. m. 52.

65 Gyárfás 1910, 233.

66 Sas Péter: A kolozsvári jezsuita, majd piarista templom kincstára. Kolozsvár 2007. Kincstár 138. és 139. szám (64-65. lap). 138. sz.: Votív. Ezüst, trébelt, poncolt. Téglalap alakú, hullámos peremü, felső ívelésü lemez. Baloldalon kezdetlegesen megformált Atyaisten-ábrázolás jobb kezét kebléhez emeli, másik kezében keresztes glóbuszt tart. Jobbra ágyékkendős, jobb kezét áldásra emelő Krisztus, másik kezében hosszú szárú keresztet tart. A körülöttük levő dicsfény fölött a Szentlélek galambja, kiteljesít- ve a Szentháromságot. Méret: $\mathrm{m}: 15 \mathrm{~cm}$, sz: $9 \mathrm{~cm}$. Jelzett: K:156 és 286; 139. sz.: Votív. Ezüst, trébelt. Négyszögletes, hullámos peremü lemez. Egymással szembenálló házaspár, balra hosszú ruhás nő, jobbra kabátos férfi. Méret: $11 \times 11 \mathrm{~cm}$. Jelzett: K:156 és 286 .

67 BÁV 53. Művészeti Aukció (2008. november 13.) 828.sz.: Brassói biedermeier cukorszóró. Ezüst, 152 gr. Trébelt, kerek, ívelt talpon amfora alakú edény, hengerelt, áttört és vésett díszítésű menetes kupak. Talpperemén jelzett: Brassó, 1830 körül, Thomas Kasten, Kőszeghy 133, 156, 287. M: 16 cm; 843. sz.: Brassói biedermeier cukordoboz. Ezüst, 392 gr, belül tüzaranyozott. Négy golyólábon álló, sarkain levágott téglatest. Enyhén boltozatos fedelén plasztikus virágbimbó. Alján tulajdonosi véset. Müködőképes zár, eredeti kulcs. Alján jelzett: Brassó, 1830 körül, Thomas Kasten, Köszeghy i. m. 156, 287. M: $8 \times 13,5 \times 10,5 \mathrm{~cm}$.

68 BÁV 58. Művészeti Aukció (2011. május 26.) 826. sz.: Brassói empire sótartó pár. Ezüst, 187 gr. Kerek, hengerelt díszítésű talpon öntött és cizellált Ádám figura. Fölötte öblös, belsejében tűzaranyozott tálka, peremén gyöngysor dísszel. Talpán alul jelzett: 12 latos finomsági jellel, Brassó 1825 körül, Thomas Kasten. Köszeghy i. m. 133, 147, 286. M: 9,1 cm, átm.: 6,6 cm.

69 Grotte András: Kísérlet néhány magyarországi ötvösjegy feloldására III. Művészettörténeti Értesítő XLIV 1995, 116-117.

70 Dorotheum 1758. Kunstauktion (30. Mai 1995.) 23.: Wiener Empire-Gewürzaufsatz. Silber, rund, hochgetriebener Fuß mit umlaufendem Blattdekor, Schaft wird durch eine vollplastische Knabenfigur gebildet, diese trägt die Schale. Höhe 11,5 cm, Gewicht $128 \mathrm{~g}$, Meisterzeichen $\mathrm{BG}=\mathrm{B}$. Gelder, Taxfreistempel, Alt-Wiener Beschauzeichen 1814.

71 Dorotheum. 1944. Kunstauktion (28. November 2000.) 288.: Paar Wiener Empire-Gewürzaufsätze. Silber, Innenvergoldung, rund, hochgewölbter Fuß mit gepunztem Ornamentband und Rosetten, ein plastischer Knabe trägt die Schale. Höhe: 10,8 cm, Gewicht $244 \mathrm{~g}$. Meisterzeichen BG = Berthold Gelder. Wiener Taxstempel, AltWiener Beschauzeichen 1816.

72 Villás Galéria és Aukciósház. 39. Festmény- és mütárgy árverés. Debrecen, 2012. május 12. 163. sz.: Füszertartó. Antik ezüst, kerek talpon álló férfi figura, feje fölött füszertartó tálkával. Bécs, 1807, 13 latos finomsági jellel. M: $12 \mathrm{~cm}$, súly: $140 \mathrm{~g}$.

73 Gyárfás 1912, 141.

74 Uo. 143.

75 Uo.

76 Köszeghy i. m. 53.

77 Gyárfás 1912, 316 és 16. jegy.

78 BÁV 48. Müvészeti Aukció (2006. május 4.) 772.: Erdélyi szász öv. Tüzaranyozott ezüst. Bársony alapon levő boglárokon Diana fémjel. Övcsaton jelzett: Brassó, 1820 körül, Christian Gust. H: 84 cm; 773.: Erdélyi szász öv. Fémszállal szőtt alapon aranyozott ezüst boglárok csiszolt üvegkövekkel. Övcsaton áttört virágdíszítés. Jelzett: 12 latos fémfinomsági jel. Brassó, 1850 körül, Adolphus Gust. K: 156, 294. H: 91 cm. 1867-1872 közötti újbóli Dianás fémjelzéssel.

79 BÁV 56. Művészeti Aukció (2010. május 20.) 657.: Empire füszertartó pár. Ezüst, 127 gr, részben tüzaranyozva. Három patás állatlábon álló öblös tálka. Oldalán 
vésett, kurzív tulajdonosi monogram. Alján jelzett: 13 latos finomsági jellel, CG mesterjegy. Brassó (?), 1820 körül.

80 BÁV 89. Ékszeraukció (2012. december 11.) 135. Karék. 16K arany, neobarokk stílusú nyitható reif, türkiz és fél gyöngydíszítéssel, belső nyitható hajfürt tartó rekesszel, nyelves zárral, 1870 körül CG mesterjeggyel, súly 22,2 gr, biztonsági lánc későbbi 14K arany pótlás.

81 BÁV 40. Művészeti Aukció (2002. április 24.). 530.: Díszöv. Aranyozott ezüst, bruttó 737 gr. Két tagból álló, áttört míves övcsattal, almandinnal díszített veretekkel Kövek kopottak. Jelzett: 12-es fémfinomsági jellel. Brassó, 1860-1865 között, Adolphus Gust, valamint utólagosan beütött osztrák Diana-fejes fémjelzéssel.

82 Gyárfás 1912, 142, 144.

83 Köszeghy i. m. 53

84 Gyárfás 1912, 318 és 32. sz. jegy.

85 BÁV 51. Művészeti Aukció (2007. november 8.) 801. Brassói empire kávéskanna. Ezüst, 620 gr. Trébelt, kerek lépcsőzetes talpon hullámosan bordázott edénytest. Kiöntőcsövén vadászkutya-fej. Talpán, nyakán és peremén hengerelt díszítmények. Boltozatos, leemelhető fedél szegecselt gombbal. Eredeti, ébenfeketére pácolt fa fogó. Tulajdonosi jelzések: kurzív VM és beütött G.Z.S. Talpán oldalt jelzett: Brassó, 1845 körül, Carolus Resch. Köszeghy i. m. 133. 289. M: $24,5 \mathrm{~cm}$.

86 Pintér Aukciósház. 2015. Karácsony. 224.: Gyertyatartó pár. Brassó. 270 és 280 gr, $28 \mathrm{~cm}$.

87 Gyárfás 1912, 142.

88 Gyárfás 1912, 320 és 51. sz. jegy.

89 Köszeghy i. m. 53.

90 BÁV 31. Művészeti Aukció (1997. október 28.) 188. Cukorfogó. Antik ezüst, 28 gr. Mindkét száron áttört, fürészelt növényi motívum, kanálvégü csiptetővel. Javított, de jó állapotban. 13-as finomsági jelzéssel, HJ mesterjegy. XIX. század második fele.

91 BÁV 48. Múvészeti Aukció (2006. május 4.) 787. Brassói biedermeier csokoládés kanna. Ezüst, 623 gr. Kerek talpon hat részre osztott gerezdelt edénytest, zsanéros fedelén virágcsokor. Fa füle pótolt. Javított. Jelzett: Brassó, 1850 körül, Henricus Jekelius (Köszeghy 157, 292). M: $23 \mathrm{~cm}$.

92 Gyárfás 1912, 143, 318 és 36. sz. jegy.

93 Köszeghy i. m. 53.

94 Óra- és Ékszerkereskedelmi Vállalat 1989. Öszi ékszer és nemesfém aukció (1989. november 28.) 6.: Szász öv. Antik ezüst, öntött cizellált nagyvirágos kéttagú csatjához vörös bársonnyal és ezüstbrokát szalaggal borított széles bőr szíj csatlakozik. Rajta tíz nagy, kúposan lemezekből felrakott boglár van, közepükön váltakozó zöld és vörös foglalt üvegekkel. Brassó, 19. sz. közepe, Eduardus Schnell. A fémrészek jó állapotban, a textil kopott, foszlott, szakadt. Btto: 1530 gr, ntto: cca 1300 gr.

95 Zoltai Lajos: Ötvösök és ötvösművek Debrecenben Debrecen 1937, 28.

96 Grotte András: Kísérlet néhány magyarországi ötvösjegy feloldására II. Művészettörténeti Értesítő XL. 1991, 71 .

97 Grotte András: Kísérlet néhány magyarországi ötvösjegy feloldására IX. Művészettörténeti Értesítő LII. 2003, 122

98 Heilbronner Kunst- und Auktionshaus, Dr. Jürgen Fischer. 121. Fischer-Auktion. Silber. 25. November 2000 240.: Kasserole. Presov 1824. Meister Elias Keler. Runder, nach oben leicht geweiterer Korpus auf drei floral relifierten Füßen. Seitl. Holzgriff mit Elfenbeinkugelknauf. Am Rand Beschau- und Meistermarke. D:12,5 cm, $340 \mathrm{~g}$. Vö. Kószeghy i. m. Nr. 621 és Nr. 646.

99 Óra- és Ékszerkereskedelmi Vállalt 1985. Őszi ékszer- és nemesfém-aukció (1985. november 26.) 238.: Kilenc érmes-kanál. Ebből 2 db. Eperjes, Elias Kéler.

100 Grotte András: Kísérlet néhány magyarországi ötvösjegy feloldására VI. Művészettörténeti Ertesítő XLVIII. 1999, 125.

101 Sotheby's New York (9. April 2008.): Fine French and Continental Furniture, including European Tapestries, Ceramics, Silver and Carpets. 54.: A German parcelgilt silver standing cup, circa 1570, the rim engraved with strapwork and classical profiles, the body applied with classical busts above vase-shaped stem, marked with a flask (cf. Jacob Frohlich of Nuremberg) and house mark, probably part of a double cup, the associated foot by another maker, slightly later. 292 gr, 17,8 cm. Otto Pick Collection, No. 275.

102 Helmut Seling: Die Augsburger Gold- und Silberscmiede, 1529-1868. Meister-Marken-Werke. München 2007, 330-331., 1663 sz. jegy.

103 Nürnberger Goldschmiedekunst. Band I. Meister, Werke, Marken. Teil 1: Textband. Verlag der Germanischen Nationalmuseums. Nürnberg 2007, 131133, mesterjegy: MZ0249.

104 Demkó Kálmán: Lőcse története. Lőcse 1897. A polgárok névjegyzéke: 270-294.

105 Eva Toranová: Goldschmiedekunst in der Slowakei. Bratislava 1982 (a továbbiakban: Toranová 1982), 242.

106 Mihalik József: Kassaváros ötvösségének története. Budapest 1900. 296. Mész (Moesz) ötvös Sámuel 16971710. 1702-1705, 1707-1710 első céhmester, 1705-1706 második céhmester.

107 Eva Toranová: Levočský zlatnícky cech v 17.-19. storoči. Sborník Slovenského Národného Múzea. Historia 7. Bratislava 1967. (A továbbiakban: Toranová 1967.)

108 Toranová 1967, 193; Toranová 1982, 242.

109 A magyar nyelv történeti-etimológiai szótára. II. Budapest 1970, 646.

110 A lőcsei evangélikus egyház házassági anyakönyve. MNL OL, Filmtár, C1581 sz. doboz.

111 A lőcsei evangélikus egyház keresztelési anyakönyve. MNL OL, Filmtár, C1579 sz. doboz. Anna Mária (1711. július 19.), Elisabeth (1713. szeptember 8.), Elias Bernhard (1714. december 3.), Catharina (1718. február 4.), Friedrich (1721. március 11.)

112 Toranová 1967, 193.

113 A lőcsei evangélikus egyház halotti anyakönyve. MNL OL, Filmtár, C1582 sz. doboz.

114 MNL OL, Filmtár, C1581 sz. doboz.

115 MNL OL, Filmtár, C1582 sz. doboz.

116 MNL OL, Filmtár, B50 sz. doboz.

117 Grotte András: Kísérlet néhány magyarországi ötvösjegy feloldására XIV. Müvészettörténeti Értesítő LXII. 2013, 74 .

118 MNL OL, Filmtár, 49722. sz. doboz.

119 25, 211, sz. 154, bekezdés 101. oldal.

120 Uo. 103. oldal.

121 Grotte András: Kísérlet néhány magyarországi ötvösjegy feloldására V. Művészettörténeti Értesítő XLVI. 1997, 212. 
122 Mihalik Sándor: A rimaszombati ötvöscéh. Budapest 1919 (a továbbiakban: Mihalik 1919), 41.

123 Uo. 52, 53.

124 Eva Toranová: Výrobky domácich zlatníkov a pamiatky zlatníckych cechov v zbierkach slovenských Múzeí. Bratislava 1968 (a továbbiakban: Toranová 1968), 172, inv. č. UH 3910.

125 Mihalik 1919, 93.

126 Mihalik 1919, 30, 33, 42, 46, 93.

127 Nagyházi Galéria és Aukciósház. 208. aukció (2015. május 29.) 953.: Füszertartó. 2006 utáni budapesti fémjellel ellátott antik ezüst, babér füzérekkel díszített, négy maszkeronos lábon álló, ovális gyürü, kiemelhetô tálkában, "SK" mesterjegy, javított, 105,7 g, $7,5 \times 5,8 \times 4 \mathrm{~cm}$.

128 Nagyházi Galéria és Aukciósház. 179. aukció (2011. december 10.) 452.: Pohár. Erdély? 17. század vége, antik ezüst, aranyozás nyomával, "GZ” ismeretlen mesterjegy, osztógyűrűvel, vésett, poncolt díszítéssel, hiányos talpperemmel, sérülésekkel, 127,2 g, M. $16 \mathrm{~cm}$.

129 Az ötlet Dobóczy Tibor úrtól származik, amiért e helyen is köszönetet mondok.

130 Mihalik 1919, 91.

131 Köszeghy i. m. 314.

132 Grotte András: Kísérlet néhány magyarországi ötvösjegy feloldására. XIV. Müvészettörténeti Értesítő LXII. 2013, 77.

133 Grotte András: Kísérlet néhány magyarországi ötvösjegy feloldására. XI. Müvészettörténeti Értesítő LVII. 2008, 132.

134 Adreßbuch der protokollirten und nicht protokollirten Kaufleute, Fabrikanten und Gewerbsleute von Ungarn, Siebenbürgen, Croatien, Slavonien, Dalmatien, Galizien und Bukowina, zugleich Handelsgeographie, Produkten- und Fabrikaten-Bezugsangabe. Nürnberg 1870. Verlag von Leuths et Comp.

\section{AN ATTEMPT AT SOLVING SOME HUNGARIAN GOLDSMITH'S MARKS XVIII}

Continuing with his earlier publications (Müvészettörténeti Értesítő) the author presents new goldsmith's marks and mark variants found in private collections and the art trade and makes an attempt to decode them. For already published marks he relies on Elemér Köszeghy's book (Elemér Kószeghy: Hungarian goldsmith's marks from the Middle Ages to 1867. Budapest 1936) and for the Pest-Buda marks on Ilona P. Brestyánszky's work (History of goldsmith's art in Pest-Buda. Budapest 1977), referring to the running numbers in these works. He presents new data about the goldsmiths of Pest, Brassó (Braşov, Kronstadt,
Romania), Debrecen, Eperjes (Prešov, Preschau, Slovakia), Lőcse (Levoča, Leutschau, Slovakia), Nagyvárad (Oradea, Großwardein, Romania), Rimaszombat (Rimavská Sobota, Gross-Steffelsdorf, Slovakia), Szabadka (Subotica, Serbia) and Szatmárnémeti (Satu Mare, Romania).

GROTTE András, H-1145 Budapest, Columbus u. 32.

Kulcsszavak: ötvösség, ezüstmüvesek, levéltári adatok, magyar városok, 17-19. század / Keywords: goldsmithing, silversmith, master's mark, archival data, Hungarian towns, 17-19th centuries 